Article

\title{
Geomorphometric Methods for Burial Mound Recognition and Extraction from High Resolution LiDAR DEMs
}

\author{
Mihai Niculiță ${ }^{1 *}$ \\ 1 Department of Geography, Alexandru Ioan Cuza University of Iași; mihai.niculita@uaic.ro \\ * Correspondence: mihai.niculita@uaic.ro; Tel.: +40-742-824-349
}

\begin{abstract}
Archaeological topography identification from high-resolution DEMs is a current method that is used with high success in archaeological prospecting of wide areas. I present a methodology trough which burial mounds (tumuli) from LiDAR DEMS can be identified. This methodology uses geomorphometric and statistical methods to identify with high accuracy burial mound candidates. Peaks, defined as local elevation maxima are found as a first step. In the second step, local convexity watershed segments and their seeds are compared with positions of local peaks and the peaks that correspond or have in vicinity local convexity segments seeds are selected. The local convexity segments that correspond to these selected peaks are further feed to a Random Forest algorithm together with shape descriptors and descriptive statistics of geomorphometric variables in order to build a model for the classification. Multiple approaches to tune and selected the proper training dataset, settings and variables were tested. The validation of the model was performed on the full dataset where the training was performed and on an external dataset in order to test the usability of the method for other areas in a similar geomorphological and archaeological setting. The validation was performed against manually mapped and field checked burial mounds from two neighbor study areas of $100 \mathrm{~km}^{2}$ each. The results show that by training the Random Forest on a dataset composed of between $75 \%$ to $100 \%$ of the segments corresponding to burial mounds and ten times more non-burial mounds segments selected using latin hypercube sampling, $93 \%$ of the burial mound segments from the external dataset are identified. There are 42 false positive cases that need to be checked, and there are two burial mound segments missed. The method shows great promise to be used for burial mound detection on wider areas by delineating a certain number of tumuli mounds for model training.
\end{abstract}

Keywords: archaeological topography; tumulus; burial mound; geomorphometry; high-resolution; DEM; LiDAR; Random Forest

\section{Introduction}

The LiDAR technology available in the '70 and ' 80 became a de facto standard for obtaining high-resolution DEMs of bare earth after the '90 [1-4]. Nowadays, these DEMs have at least regional or even national coverages in some parts of the world, and their usage through visualization and/or automatic/semi-automatic recognition of features has become a research direction that has wide implications in geosciences [5,6] or archaeology [7-23]. In archaeology the usage of LiDAR is becoming a standard in archaeological mapping at regional [24] and national scale [25]. The availability of computation hardware and software, together with high-resolution DEMs makes possible and feasible this approach for different types of landforms, natural or anthropic.

The high-resolution DEMs obtained using from LiDAR data can represent a source of information for the geomorphologist or the archaeologist, even under forests [10]. There are limitations [26], concerning technology but also the features that can be recognized. The visualization 
of the DEM, together with other geomorphometric variables can increase the quantity of information that can be recognized [27-35]. When the features that need to be identified are rather small, cover wide areas and are in big number, automatic or semi-automatic methods for their identification and delineation can improve the creation of inventories [36-40]. These considerations apply the best to archaeological features that appear as mounds or holes [41-44]. There are approaches that rely solely to optical satellite imagery [32,45] or other types of geophysical data [46].

\section{Study area}

The study area is located in north-eastern Romania in the Jijia Hills (Figure 1 inset), a hilly area developed on monoclinic Miocene rocks. The hills are in general asymmetric, because of the monoclinal structure and of the homoclinic shifting of the channel network [47], which also developed wide floodplains ( 0.5 to $2 \mathrm{~km}$ width). Two neighbor square areas of the same size $\left(100 \mathrm{~km}^{2}\right)$ were chosen for training and validation (Figures 1 and 2). The northern study area (Figure 1) was used for training and internal validation, while the southern study area (Figure 2) was used for external validation.

In the study area, the archaeological literature mentions a main period when burial mounds were built: Bronze Age (5450-2450 yr BP), during which several cultures [48] constructed mounds for burial purposes: Jamnaya (5200-4450 yr BP), Catacomb (4550-3950 BP), Srubnaya (3950-3250 yr BP).

$[49,50]$ are one of the first archaeologists to investigate burial mounds in the study area, at Glăvăneştii Vechi (Iaşi County) and Corlățeni (Botoşani County) and to find graves and goods that attribute the burial mounds to Yamnaya culture. These Yamnaya burial mounds are present on a large geographical area, in Eastern and South-Eastern Europe [51,52] and appear in Moldavian Plateau on various landforms: ridges (Corlățeni -[50]; Movila Carului from Şuletea - [53]), hillslopes (La Stadole [50]), lower fluvial terraces (Valea Lupului - [50]) and on floodplains (Glăvăneştii Vechi - [49]). The main characteristic of these burials is the presence of red ochre which covered the dead body. Other Jamnaya and post-Jamnaya burial burials were described in the proximity of the study area by [53-55]. Very often, the bronze age burial mounds were used by Hallstatt, Sarmatic or Turanic populations for secondary burials [55-58].

In Moldavian Plateau, burial mounds appear all over the area, with decreased densities at higher altitudes and in the Central Moldavian Plateau and Tutova Hills. The biggest density of burial mounds is in Jijia Hills. An extensive spatial inventory of mounds was made by [59] for Botoşani County. This inventory registers only the presence of a burial mound and sometimes the height of the mound, without mapping the spatial extension. A quick view on LiDAR data or satellite imagery for Botoşani County shows us that this inventory is not complete, many burial mounds not being identified in this inventory.

Burial mounds in the study area were first described in 1872 [60]. Their locations cover both forests and arable lands, ridges, hillslopes, or floodplains, and their origin was attributed to humans. A particular impressive discovery is related to a mound eroded by Podriga river in 1811, which revealed a grave with important gold artifacts [60]. The discovery reveals the situation that local populations were aware of these discoveries and considered these mounds as treasure locations. It is not strange that many mounds bear the marks of old excavations in search of gold treasuries.

The investigation of $[49,50,61]$ and other recent investigations [62] show that the present-day morphology of the burial mounds is not the same as when these features were constructed (Figure 3). Their initial shape was of a truncated cone. Natural and human induced erosion tends to bury the basal edge of the structure and to flatten the upper part. Often, beside the burial of the basal edge, in this area a concave surface appears, because the terrain beside the mound is not ploughed, and the last plough row is deposited in its vicinity. This situation makes their identification and delineation difficult in extreme cases, where the initial topography is heavily smoothed. In such cases, satellite images from the spring or autumn season, when the agricultural fields are tilled could be used to identify the burial mounds [38], the soil developed on these features having lighter colors than the A horizon of the surroundings soils (chernozems and faeozems). 


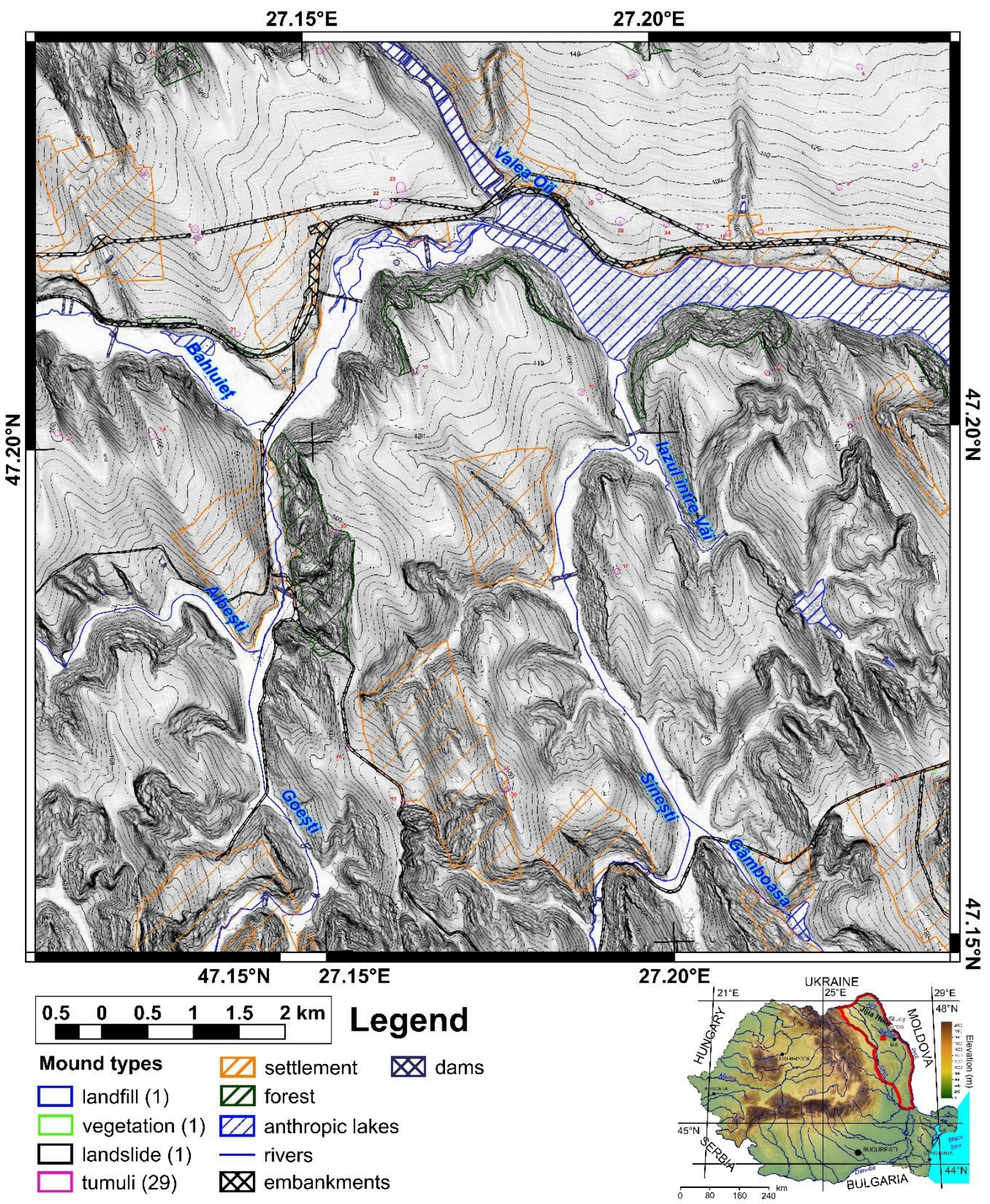

Figure 1. The geographic position of the northern study area and the location of the delineated mounds. https://doi.org/10.6084/m9.figshare.11798517.v2

\section{Materials and Methods}

\subsection{LiDAR data}

LiDAR data used in this study was acquired at the beginning of 2012 using a Leica ALS60 system by a company commissioned by Prut-Bârlad Water Administration. The original point cloud data $\left(21708 \mathrm{~km}^{2}\right)$ in geographic coordinates on the ETRS89 datum (EPSG:4258) was classified by the producer using an unspecified algorithm and converted to ASPRS 1.1 format classes. Data georeferencing was realized using a network of 387 geodetic points, measured both in ERTS89 and 
Stereo 70 Marea Neagră datums and for which a quasi-geoid model was computed. The LiDAR point density is between 2 and 6 points per $1 \mathrm{~m}^{2}$.

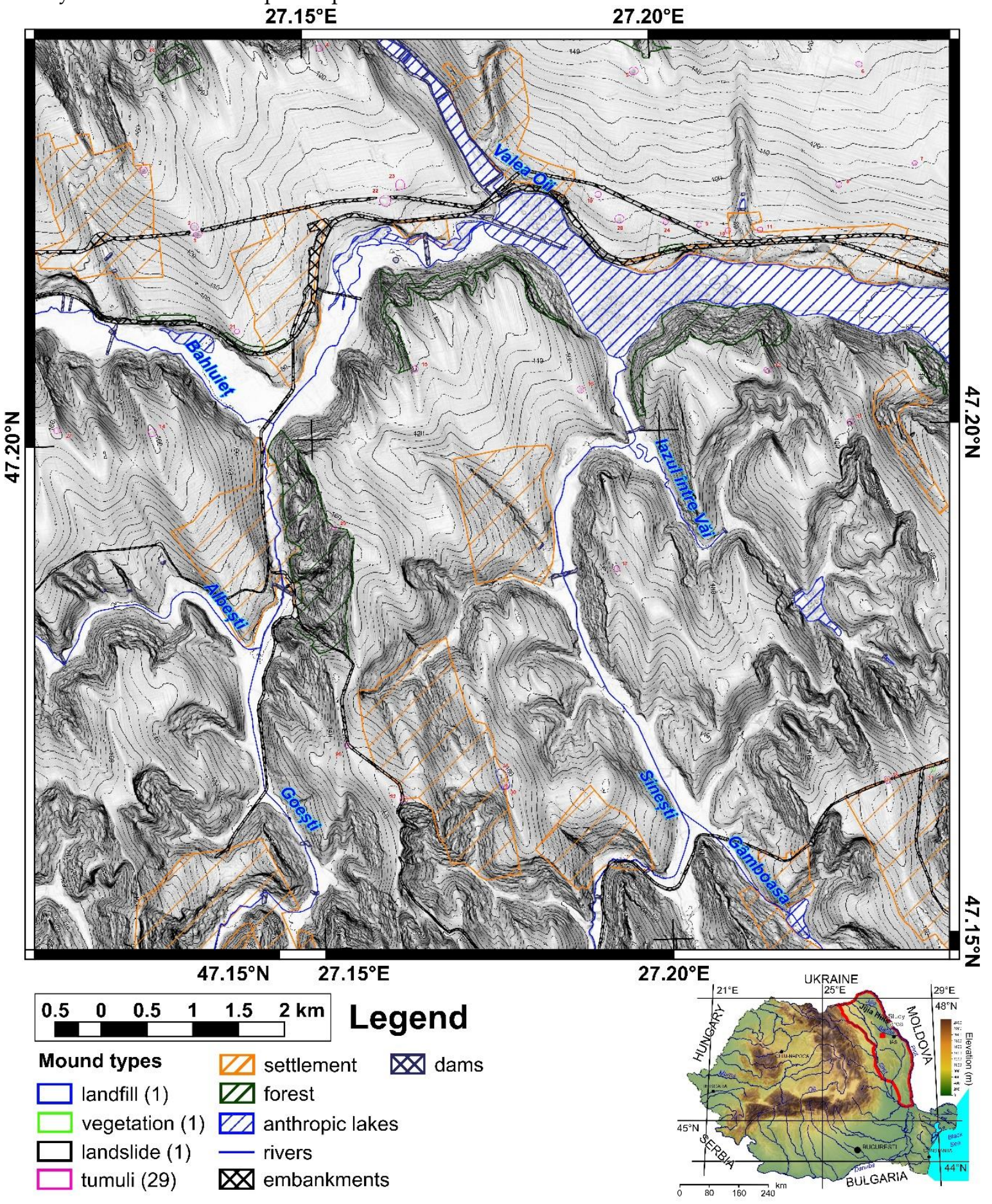

Figure 2. The geographic position of the southern study area and the location of the delineated mounds. https://doi.org/10.6084/m9.figshare.11798613.v2

The point cloud was filtered to exclude vegetation and man-made features and to obtain a bare earth DEM at $0.5 \mathrm{~m}$ spatial resolution. The result is a good bare earth DEM, because the data was acquired in late winter, and the study area has low forest cover, but there are several areas were the algorithm for point cloud classification failed: in forests and on reservoir deltas were the lower vegetation is very dense, or in the built-up areas. The final DEM was resampled with a bicubic interpolator at $5 \mathrm{~m}$ spatial resolution. 


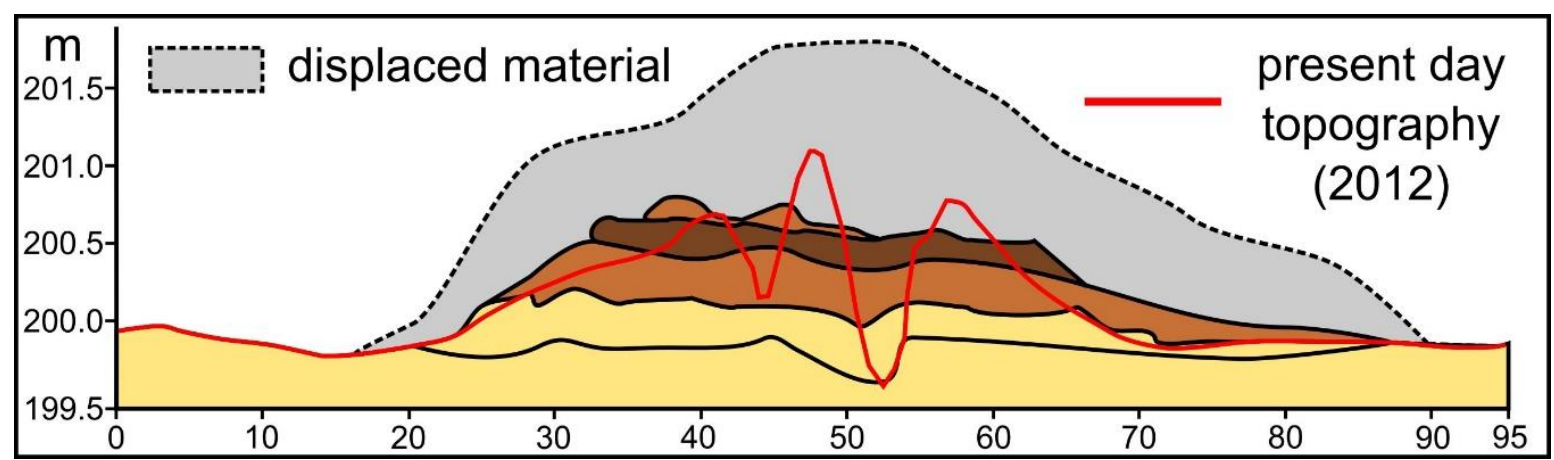

Figure 3. The stratigraphy of a burial mound (yellow to brown and grey) excavated by [61] at Corlățeşti (Botoşani, County), redrawn after [61] with overlayed present day LiDAR topography (red line); the location of this mound is represented in Figure 2 of [63], available in high-resolution at https://doi.org/10.1371/journal.pone.0227335.g002 or https://doi.org/10.6084/m9.figshare.11340419. https://doi.org/10.6084/m9.figshare.11798616.v1

\subsection{Mound manual delineation and field recognition}

First, using the LiDAR DEM, shading, slope, aspect, curvatures and contours in 2D and 3D views, different types of mounds were delineated as polygons that represents the basal edge of the mounds for the northern (98 mounds) and southern (32 mounds) study areas. The delineated mounds were latter checked on aerial imagery and in the field to assign an attribute (Figures 1 and 2) as it follows for northern study area: burial mounds (69), landfills (8), DEM interpolation error (1), non-filtered high vegetation features (7), wrongly classified LiDAR points (1), landslide body terrain rough features (2), meander cut-off island (1), mounds (3), water reservoir (1), electric pole base (5). For the southern study area, from 32 mounds, 29 are burial mounds while landfills, vegetation and landslide body, are one mound per feature.

Mounds are landforms created by different processes, but with similar morphology, situation that can be associated with geomorphometric convergence, similar with the morphological convergence from biology [64]. The overall shape of the landform alone cannot always be used to specify exactly the process that created it. That is why all the burial mounds were verified in the field and the classification from remote sensing images was validated (Figures 1 and 2). Only two mistakes (delineated as burial mounds, found to be something else) were revealed by the field validation (IDs 35 and 94, in Figure 1, S4 and S10). The validation was based not on geophysical or archaeological prospection but on the geomorphological observation of the morphology in the field. In general, the burial mound vs. non- burial mound distinction is easy to be done both on remote sensing images and in the field, especially for a trained person (both regarding the local geomorphology and archaeology of the study area). There are not many natural processes that can produce landforms with a shape similar with a burial mound. Humans instead can produce various types of mounds through deposition of materials, and the type of material is an indication of the mound typology. I delineated anthropic burial mounds or natural features (vegetation not filtered from the point cloud and landslide body rough features only when these had similar shape and size with burial mounds). The best field pictures for showing the presence of a burial mound are taken from a neighbor ridge (Figure 4), especially in the case of smoothed burial mounds.

\subsection{Geomorphometrical methods}

Since geomorphometry deals with the quantitative depiction and analysis of Earth surface [65], the use of geomorphometrical variables [66] and methods of geomorphometrical object delineation [67] appears to be the right approach [68]. Supervised and unsupervised geomorphometrical methods for landform detection and delineation [67] are based either on statistical methods or on a priory models of process-form systems $[69,70]$. Their classification as pixels or objects is done depending on the composition of the final object that is delineated. I have used both types of 
geomorphometric object classification and delineation (Figure 5): a system of surface specific points [71-73] and a statistical classification (Random Forest). 


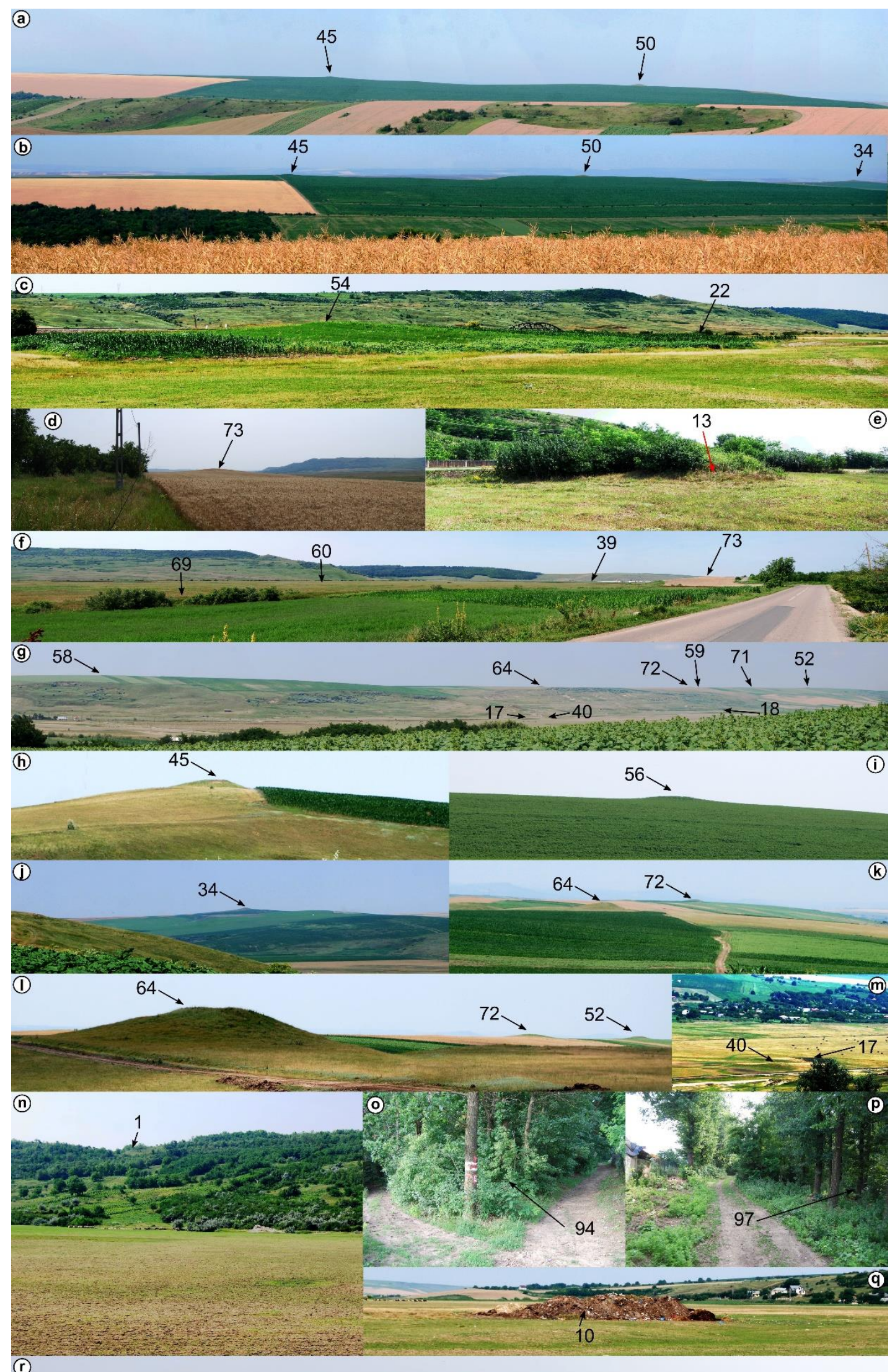

(1)

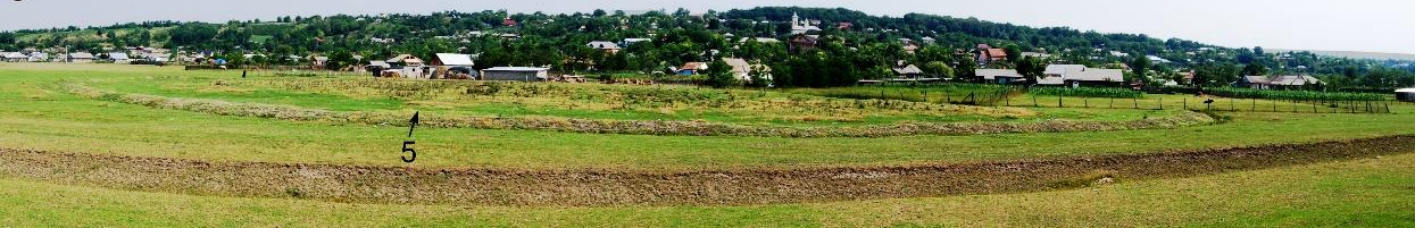


Figure 4. Field photos for verification (the numbers are the burial mound IDs from Figure 1): a - burial mounds 45 and 50 as seen from burial mound 36; b - burial mounds 34, 50 and 45 as seen from burial mound 46; c - burial mounds 22 and 54; d - burial mound 73; e - burial mound 13; $\mathrm{f}$ - burial mounds $39,60,69$ and 73; $\mathrm{g}$ - burial mounds 40,52, 58, 59, 64, 71, 72, mounds 17 and 18; $\mathrm{h}$ - burial mound 45 seem from south; i - burial mounds $56 ; \mathrm{j}$ - burial mound 34 seen from burial mound $62 ; \mathrm{k}$ - burial mounds 64 and 72 seen from burial mound 58; 1 - burial mounds 64, 72 and 52; $\mathrm{m}$ - burial mound 40 and mound 17; $\mathrm{n}$ - landslide; $\mathrm{o}$ and $\mathrm{p}$ - vegetation; $\mathrm{q}$ and $\mathrm{r}$ - landfill. https://doi.org/10.6084/m9.figshare.11798625.v1

The peak extraction was performed using the search of the maximum value in a focal window. If the elevation value was the highest in the focal window, it was assigned as a peak. Twelve focal window sizes of square shape were tested: from $3 \times 3$ to $25 \times 25$. The method proposed by [71] can be easily implemented in any GIS software which has scripting capabilities. We have used the R statistics software [74] which is open source and has GIS and remote sensing capabilities through various packages [75-78].

The logic behind the method proposed by [71,73] was followed, but the implementation required a different step by step procedure since the framework for implementation is different. The maximum value of elevation in square kernel windows ( $3 \times 3$ to $25 \times 25$ pixels) was computed using the focal function from the raster package [77], and using a user defined $\mathrm{R}$ function applied through the overlay function from the raster package we checked if the value of elevation for every pixel is higher or equal with the focal maximum. This is true for peaks and false for non-peaks. Peaks were flagged with value 1 and non-peaks with 0 value.

Because the local peaks appear on many rugged features, local convexity is used to differentiate the burial mounds, which are essentially local convex features of a certain horizontal and vertical extension of elevation, from the dissimilar local peaks of the rugged landform surface. Local elevation maxima correspond with local convexity maxima, and the change in convexity is marking the mound edge. The mounds are different in scale compared to the small-scale ruggedness, the convexity varying on longer distances for mounds compared to other small-scale convex features. That is why in order to identify mounds, watershed segmentation [79-82] was applied to terrain local convexity computed by the SAGA GIS 7.4.0 [83] implementation of [84] algorithm in a 5x5 pixels window size, using a Laplacian filter with 8 pixels neighborhood (Terrain Analysis / Morphometry / Terrain Surface Convexity).

Local terrain convexity at every grid cell is expressed in percentage values of convex cells in a certain radius of cells [85]. I used a 5x5 area in order to smooth the local outliers, and in Figure 6 it can be seen that local peaks get $100 \%$ local convexity while the basal part of the mounds get values close to $10 \%$. True flat terrain will have $0 \%$ local convexity. The flat area threshold controls the $0 \%$ percent values. If 0 is chosen as threshold, only no slope pixels will get this value. As the threshold increase, more areas will have $0 \%$ local convexity. Beside the implementation that computes the number of cells, which will give multiple maximum (100\%) pixels on the maximum concavity (by counting cells), there is also a method that applies a resampling to cell counting, and which will give only a maximum value pixel (Figure 6).

The watershed algorithm implemented in SAGA GIS [83] works in two phases. In the first phase seeds are generated (which are either local minima or maxima), and the seeds are growing pixel by pixel until a certain threshold is reached or to simply put it if the digital surface changes its trend (from ascending to descending or vice-versa). Since the burial mounds are convex features the local maxima was used for seed extraction.

The peaks obtained in the first step were refined through an $\mathrm{R}$ focal raster function that selected only the peaks that have in the $3 \times 3$ kernel window a local convexity seed, and are considered "selected peaks". The local convexity watershed segmentation polygons resulted were kept, and considered burial mound candidates based on the condition that contain at least a single selected peak.

Beside the mentioned geomorphometrical variables I also computed a wide range of variables described in Table S1. These variables were chosen considering that their values can describe the 
geomorphometric signature of burial mounds, by visual inspection and by boxplot comparison. Slope was computed by the [86] implementation of [87] slope algorithm in a $5 \times 5$ pixels window size and constrain on the central cell in SAGA GIS [83]. I have chosen this algorithm because it is smoothing the slope values, emphasizing the peaks. The full set of curvatures was computed from the same implementation. Negative openness and positive openness (morphometric protection index) were computed using the multiscale implementation of [88] algorithm from SAGA GIS in degrees difference from nadir as units. The radial limit of 100, with a multiscale factor of 3 and 8 sectors were used in order to emphasize local peaks. Index of convergence $[89,90]$ was computed as aspect difference to the center cell in a 10x10 pixels window, emphasizing local peaks with local prominence. Real surface area was also considered, beside terrain ruggedness index [91], vector ruggedness measure and terrain texture [84] as measures of roughness. Wind exposition index [92,93] as dimensionless index show shadowed vs exposed areas to wind, while topographic position index [94-96], as a multi-scale implementation in SAGA GIS, pinpoints with high positive values local peaks. Upslope and downslope curvatures [97] computed using the gradients of the neighbor pixels in upslope and downslope contributing area computed by multiple flow direction, define local convexities. Flow accumulation, flow path length, slope length, valley depth [98](as the height above downslope area) and cell balance [99] with low values and a minimum centered on the peak also pinpoint local convexities. Topographic wetness index $[98,100]$ in its SAGA GIS implementation has local minima on mounds.

Shape descriptors computed by SAGA GIS $[101,102]$ were also included as morphometric variable of the segments: area $(A)$, perimeter $(\mathrm{P})$, interior edge ratio $(\mathrm{P} / \mathrm{A})$, equivalent projected circle diameter $\left(2^{*} \operatorname{sqrt}(\mathrm{A} / \pi)\right)$, sphericity $\left(\mathrm{P} /\left(2^{*} \operatorname{sqrt}\left(\mathrm{A}^{*} \pi\right)\right)\right)$, shape index (the inverse of sphericity), maximum diameter (Dmax), and Feret diameters. The ratio between the diameter of the local convexity watershed segment and its difference in elevation was computed as a measure of mound geometry. Beside the SAGA shape descriptors, compactness, form factor, roundness and elongation were computed.

\subsection{Statistical processing and testing}

The burial mound candidate watershed segments kept using the condition to contain a selected peak were further classified using a statistical method. The descriptive statistics (minimum, maximum, sum, mean, median, standard deviation, range, variance, multiple of 5 percentiles) of the geomorphometrical variables mentioned in section 3.3 were derived for every watershed candidate segment by the SAGA GIS module Grid Statistics for Polygons.

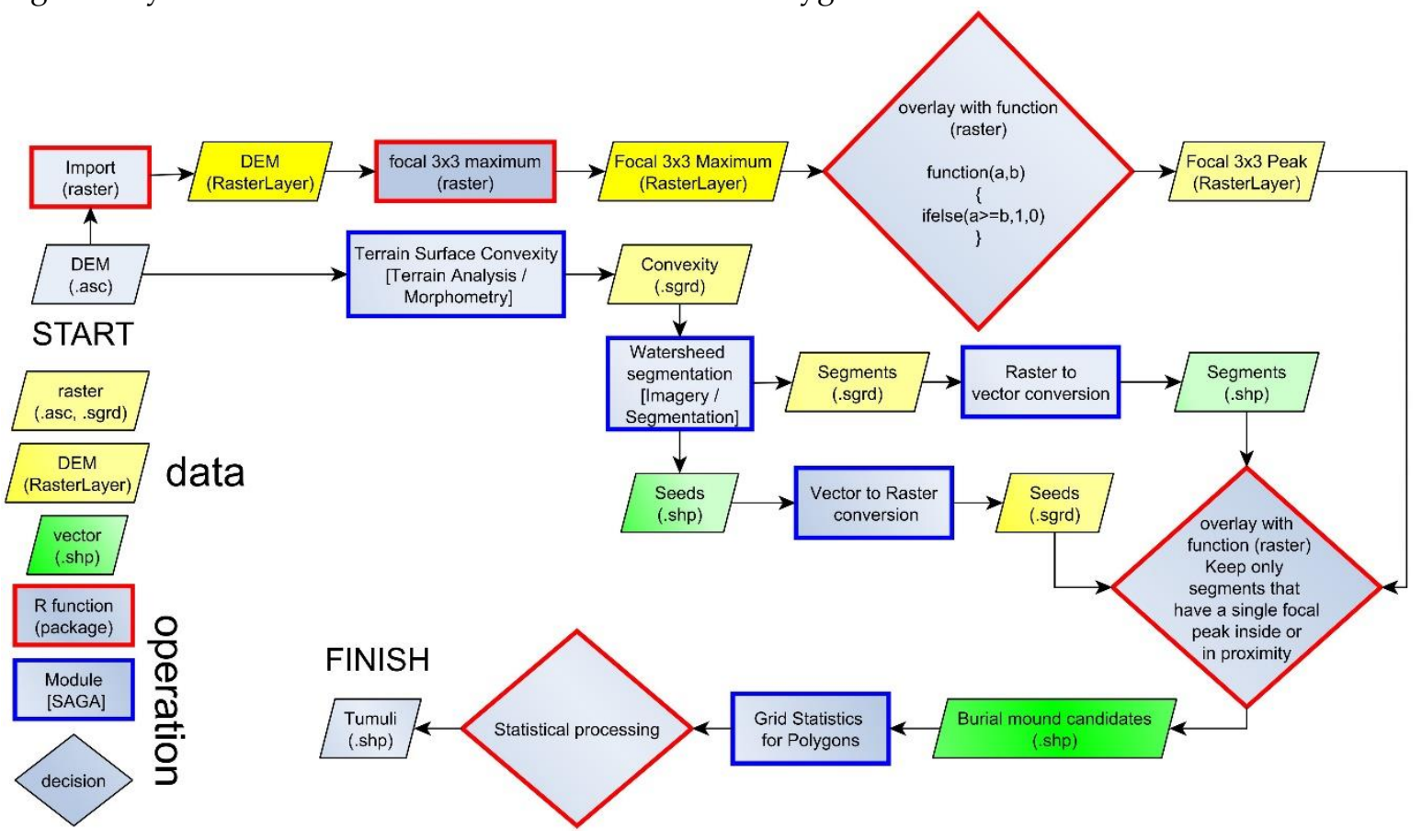


Figure 5. The proposed workflow. https://doi.org/10.6084/m9.figshare.11798634.v1

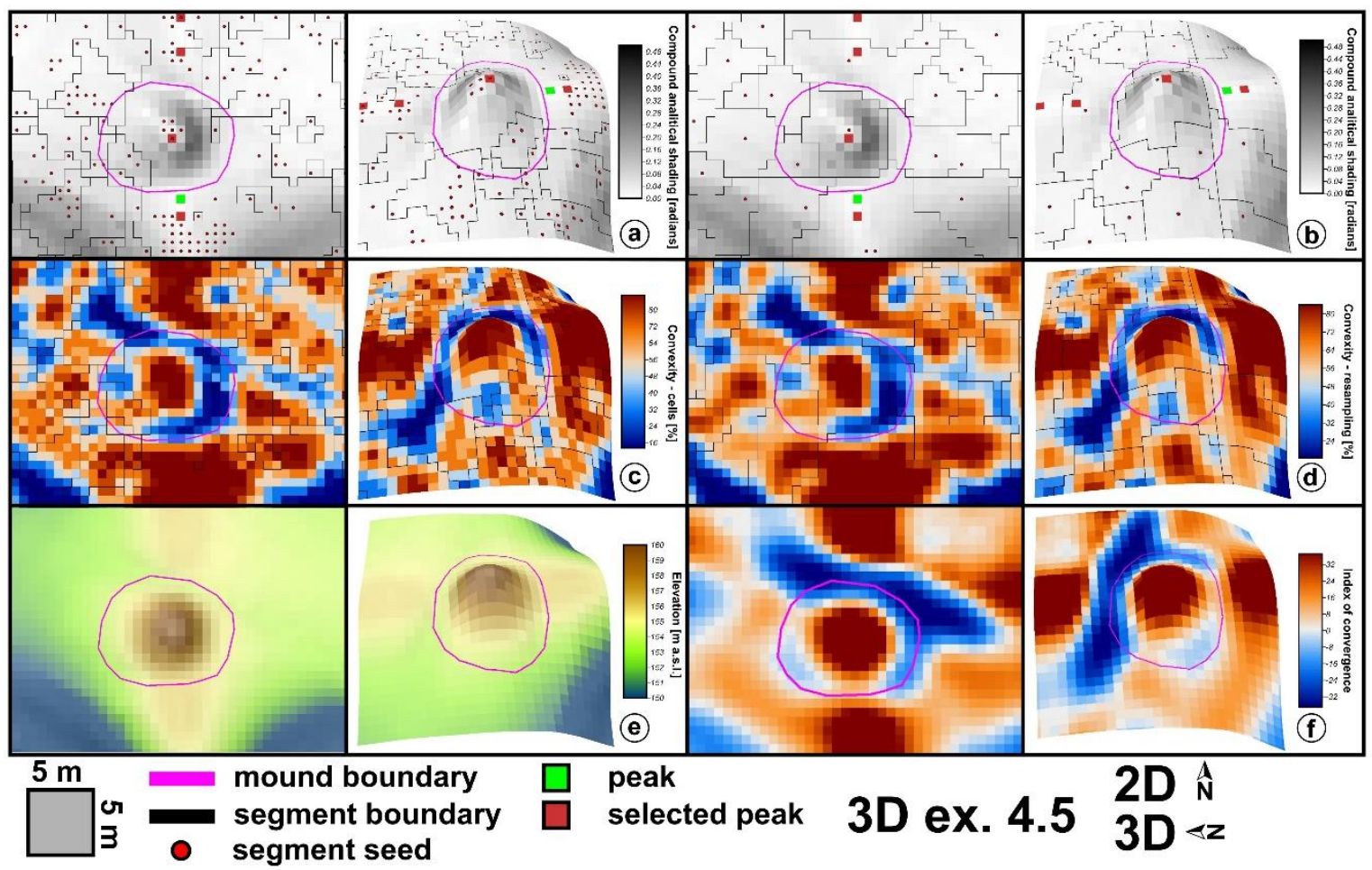

Figure 6. The geomorphometric data for burial mound 64 in 2D (left) and 3D (right): a - peaks, seeds and segments for local convexity computed with cell counting; $b$ - peaks, seeds and segments for local convexity computed with cell count resampling; c - local convexity computed with cell counting; $\mathrm{d}$ local convexity computed with cell count resampling; e - DEM; f - index of convergence. https://doi.org/10.6084/m9.figshare.11798637

Random Forest (RF) algorithm [103] implemented in R statistical software [74] as randomForest package [104] was used to classify the burial mounds from the burial mounds local maxima watershed segment candidates. The random decision forests method for classification is a versatile machine learning algorithm, that has some desirable properties: does not overfit, is accurate by being less prone to noise induced errors and can be used with high dimensional and massive data with weak inputs $[103,105]$. The classification problem in our case is a binary one and imbalanced.

The RF model for classification performs five steps [103,105,106]: (i) first ntree bootstrap samples are randomly sampled with replacement from the training dataset (with 1/3), (ii) second, for each bootstrap sample an unpruned classification tree is grown, at each node of the tree, randomly sampled mtree of the predictor variables being used to choose the best split, (iii), third, prediction is based on the aggregation of the predictions of the ntrees by majority of votes or specified cutoff, (iv), forth, estimate error based on aggregation of the out-of-bag error (OBB - error computed from predicted data on the data not in the bootstrap sample), and (v) fifth, rate the variable importance based on how much prediction error increases when that variable is not considered.

The RF model parameters were derived with tuning functions from randomForest [106] and randomForestSRC [107-109] packages, while randomForestExplainer [110] and pdp [111] packages were used to visualize the results of the model. The mtry and nodesize tuning was performed using the tune function from randomForestSRC package. For selecting the best performing variables crossvalidation was used with the functions rfcv from randomForest [104] and boruta from Boruta [112] $\mathrm{R}$ statistical software packages. Based either on the importance or on the Boruta methodology the most important variables are selected.

The cutoff parameter was used to set the probability used for the classification. Since the positive class (burial mounds) has a low proportion in the dataset $(0.6 \%)$ we computed the cutoff probabilities as frequencies of the classes. Beside this, the classwt parameters was used, which favors one class or 
the other. Also, the imbalanced two class problem solutions implemented by $[107-109,113]$ in randomForestSRC package were used.

The setup of the training and validation schema was designed in order to argument for a future application to the entire Moldavian Plateau region. The training was performed on the tumuli candidate segments dataset of northern study area and validated internally on the whole dataset of tumuli candidate segments of the northern study area. The external validation was done on the dataset of segments from the southern study area. This setting of training assumes that by mapping a set of burial mounds from the entire area, fitting the model on them will give a certain prediction power when applied for the entire area. The training was done on a subset by conditioned Latin hypercube sampling implemented in R stat chls package [114-116].

\subsection{GIS implementation and reproductibility}

The proposed workflow can be easily implemented in any GIS software which has scripting capabilities. I have used the R statistics software [74] which is open source and has GIS and remote sensing capabilities through various packages [75-78]. One such packages offers the possibility to run also SAGA functions [117]. I have created an R script which can perform the extraction based only on the DEM. The script is available on Zenodo (https://doi.org/10.5281/zenodo.3628805) together with the burial mound delineation and segments (https://doi.org/10.5281/zenodo.3628795), while the DEM data is available by request.

\section{Results}

\subsection{Burial mound geomorphometry}

The geomorphometric signature of the burial mounds can be assessed both by inspecting in 2D or $3 \mathrm{D}$ view the delineation overlayed with the geomorphometric variables and by boxplots that show the statistical distribution. In Figure 7 some geomorphometric variables of the delineated mounds are shown. Burial mounds from the northern study area (left in every boxplot from Figure 7) and those from the southern study area (center in every boxplot from Figure 7) have similar descriptive statistic measures, compared with the non-burial mounds. The most striking feature is the big number of outliers, but also mean and distribution significantly different of non-burial mounds versus burial mounds.
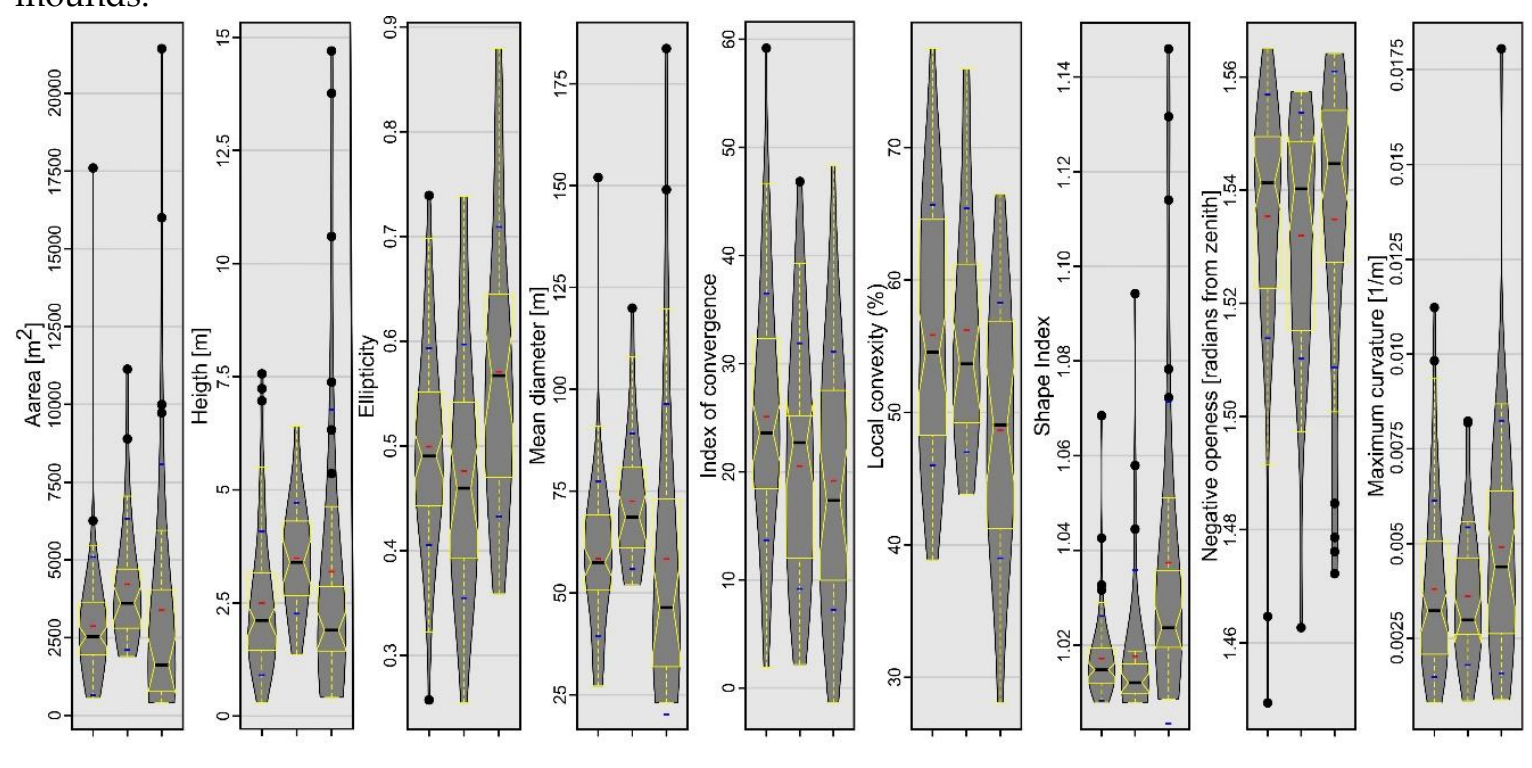

Figure 7. The descriptive statistics of burial mounds geomorphometry (black dots - outliers, black horizontal line - median, red horizontal line - mean, blue horizontal line - \pm standard deviation, grey polygon - kernel density, yellow boxplot with notch - interquantile range representing $50 \%$ of the data, upper part representing the $75^{\text {th }}$ percentile, while the lower part the $25^{\text {th }}$ percentile, lower whisker - minimum, upper whisker - maximum, notch - 95\% confidence interval of the median), for 
the fitting area (left, $\mathrm{n}=68$ ), for the testing area (center, $\mathrm{n}=29$ ) and other mound types geomorphometry (right, $\mathrm{n}=33$, for both the northern and the southern study areas). https://doi.org/10.6084/m9.figshare.11798646.v1

This situation can be explained by the fact that the non-burial mounds have shapes and morphology different form the burial mounds. While burial mounds have a conical shape, non-burial mounds might have several peaks and a not so smooth surface. Also, since are newer, do not present the basal concavity (Figure 6 and the topographic cross-sections from S1-S14) of the burial mounds, which is created mainly by the tillage.

The most striking geomorphometric feature that was observed in the delineation work was the conic shape of the burial mounds, in this regard, the geomorphometric variables related to the convex curvature (local convexity, maximum curvature, index of convergence) and those related to local prominence being the ones that individualize the best these features (negative openness and hydrologic variables).

\subsection{Burial mound peak detection}

The detection of the burial mounds starts from the idea that such features are typical geomorphometric peaks, local maxima of elevation. These peaks are local [118] but are evident at landform spatial resolutions of several decameters, and can be distinguished from the local noise. In the same time, local maxima which have the geomorphometric conditions of being peaks at similar landform resolution with the burial mounds are represented either by other man-made features (deponia, road embankments), by errors in the acquisition, classification or interpolation of LiDAR data or by other natural features. Such natural features are represented by fragmented natural levee, river meander cut-off islands, ridges, or landslide body rough topography. It is to be expected that the method will find many false positive features, that are not burial mounds. This is not necessarily a bad point of the methodology, since the targeted morphology is identified. This would be reasonable if this number is low enough to allow reasonable manual inspection of the results.

The use of the focal filters to identify maxima eliminates the local peaks located along hillslopes, and emphasizes any local peak located on floodplains, plateaus or ridges. For the focal window sizes from 3 to 25 pixels, the following number of peaks were found for the northern study area: 31543, $10857,5447,3176,2047,1434,1016,795,625,504,418,360$. At $3 \times 3$ focal window, for the northern study area from 69 burial mounds only two $(2.9 \%)$ do not have corresponding identified peaks (burial mound 85 and 90 from Figure 1, S9 and S10). This number increases to four (5.8\%) at 5x5 up to 9x9 pixels focal window size, after which is increasing continuously toward $25(32.2 \%)$ at $25 \times 25$ pixels focal window size. Bigger focal window sizes decrease the number of peaks found inside the delineated burial mounds. The number of peaks is relatively stable between $3 \times 3$ and 9x9 pixels windows size (Figure 8), after which their number decrease quickly. This means that the burial mounds have diameters between 15 and $45 \mathrm{~m}$, which is consistent with the delineated burial mounds geomorphometry (Figure 7).

For the southern study area 29726 peaks were identified, one burial mound not having an associated peak. The burial mound with ID 25 is located on a hillslope and is cut by the national road embankment, due to smoothing having a shoulder rather than a peak.

Local convexity will smooth as the window size for computation increase, the $5 \times 5$ size being a trade-off that works the best: only 3 burial mounds do not have peaks with seeds at $5 \times 5$ window size computation, while for wider window sizes the number will increase. Using $3 \times 3$ size the number of burial mounds that do not have peaks is also high, mainly because at that size very local convexity is found, but the burial mounds are not delineated well as watershed segments.

Another issue appears due to local convexity computation method. When cell count is used there are many seeds (pixels with $100 \%$ local convexity) and only three burial mounds do not have selected peaks. But the corresponding watershed segments do not delineate very well the burial mound, situation which will influence the final step of statistical processing of the segments in order to derive the identified burial mounds. In the same time using the seeds obtained from local convexity 
computed using the cell count resampling method for peak selection 14 burial mounds will not have selected peaks identified. In order to resolve the issue, I used for peak selection the seeds obtained from local convexity computed with the cell count method and the watershed segments obtained from convexity computed with the cell count resampling method. These watershed segments delineate better the burial mounds.

For the northern study area from 31543 peaks identified at 3x3 pixels windows size, through the proposed automatic methodology 26220 are selected peaks. Two burial mounds are missed by the peak selection algorithm: burial mounds 55 and 76, and adding the other two missed because of peak inexistence (with ID 90 and 85), raises to four (6\%) the number of missed burial mounds.

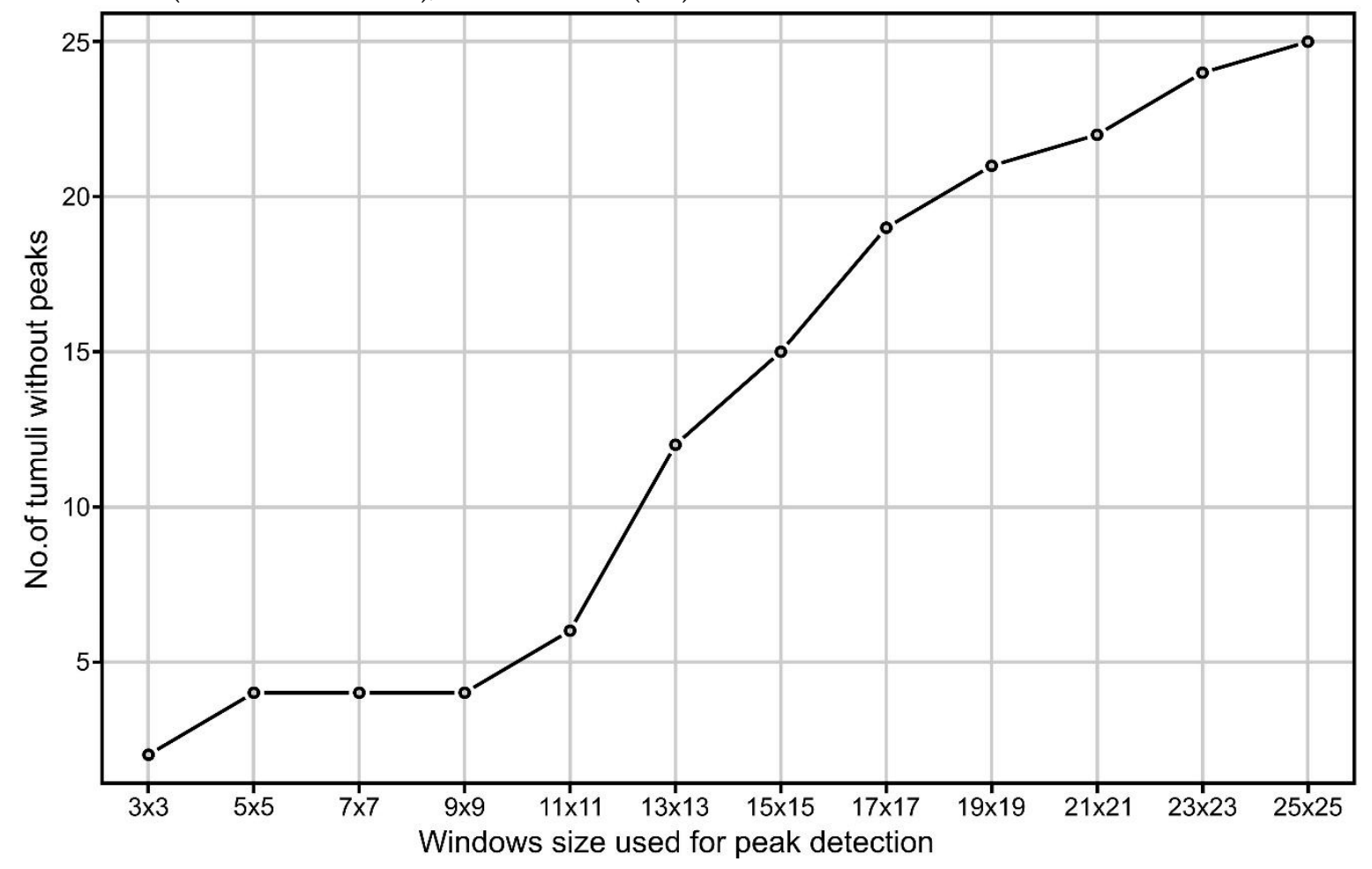

Figure 8. The variation of the number of delineated burial mounds without an identified peak as a function of the windows size in pixels used for peak identification. https://doi.org/10.6084/m9.figshare.11798652.v1

Regarding the other mounds identified by the manual mapping and field inspection, landslide mounds with IDS 1 and 14, and vegetation mound with ID 94 are not identified by the proposed method, while the others are identified.

For the southern study area from 29276 peaks, 24733 are selected, and 28 burial mounds have a selected peak. Burial mound with ID 24, which does not have a peak is located on a hillslope and is cut by a road embankment, having a shoulder shape. Burial mound with ID 23 has selected peaks, but not on the watershed segment that is central to the mound.

\subsection{Burial mounds segments candidates}

For the northern study area from 102936 terrain convexity segments, 16939 have corresponding peaks, from which 64 correspond to real burial mounds. 15602 terrain convexity segments have at least a corresponding selected peak. The majority of the burial mound candidate segments are located along the Bahlui floodplain. Over the rest of the study area these candidate segments are located mainly along the ridges and floodplains. For the southern study area from 103741 terrain convexity segments, 15840 have corresponding peaks and 14438 have corresponding at least a selected peak, from which 28 correspond to real burial mounds.

Before running the RF classification, 2343 segments corresponding to anthropic lakes not masked from the LIDAR data were removed, together with very small (under $100 \mathrm{~m}^{2}$ ) and large (over 
$5000 \mathrm{~m}^{2}$ ) segments considered outliers (2456 segments), dams and anthropic levees (622 segments) and road or rail embankments (2753 segments). The filtering of the segments can be done further if there is knowledge about areas improbable to contain burial mounds (landslides, urbanized or forested areas). Finally, 12745 burial mound segment candidates were selected for the classification step. For the southern study area 10606 burial mound segment candidates were selected for the classification step, after eliminating segments corresponding to lakes (3726 segments), dams and anthropic levees (622 segments) and road or rail embankments (2753 embankments).

First, the RF model was fitted with all the 751 variables (shape indices and descriptive statistics of elevation, local convexity, slope, maximum curvature and negative openness) computed as mentioned above. Ten-fold cross-validation shows that using around 183 of variables, the error are the lowest (Figure 9). While the RF can be used also for variable selection, based on its derived metrics, in our case lowering the number of input variables to 10 best variables (chosen based on mean decrease in accuracy measure) actually give worse results when the confusion matrix is investigated. This happens because in the RF model if the nodesize is 1 (the ntrees are grown to their maximum depth), the model will create deeper trees, so overfitting will not happen, even there are many variables. In this study case with extremely unbalanced class frequencies the combination of a big number of trees and deeper trees will learn even from slight variations of variables that might appear to be correlated otherwise.

Three number of trees was tested (100, 1000 and 10000), since a very big number does not necessarily improves the results, more important being the depth of the trees, but in the same time the number needs to be high enough to get stable estimates of variable importance and proximity [106]. The results of the RF tuning show that mtry 5 and nodesize 1 give the lowest OBB error (Figure 10) for up to 10000 ntrees. In order to keep the computational part at a minimum, and without losing accuracy 100 ntrees were used. The main issue in this regard is that indeed OBB is the lowest but in terms of accuracy matrix for our imbalanced problem actually the mtry of 4 is better (Table 1).

In the present case since the class frequencies are extremely imbalanced (burial mound class $0.6 \%$ for the northern study area and $0.2 \%$ for the southern study area) I chosen to control this through the classwt parameter of the randomForest function from randomForest package. This parameter will modify the majority vote at node split, by replacing it with vote fraction. I have used 0.01 for the nonburial mound class and 0.9, for burial mound class. This setup is giving better results both in term of OBB error and confusion matrix than the 0.5 cut-off parameter of the randomForest function or the imbalanced RF implementation of [113] from randomForestSRC package.

The randomForest model has good accuracy, given by the OBB error at various training set sampling settings (Table 1), although the most accurate RF model in terms of OBB error is not necessarily the better in terms of confusion matrix. The confusion matrix results I consider to give the final answer regarding the settings of the training dataset. Ideally in the burial mound classification problem the model should predict as many as burial mounds possible, while having a minimum of false positives. 


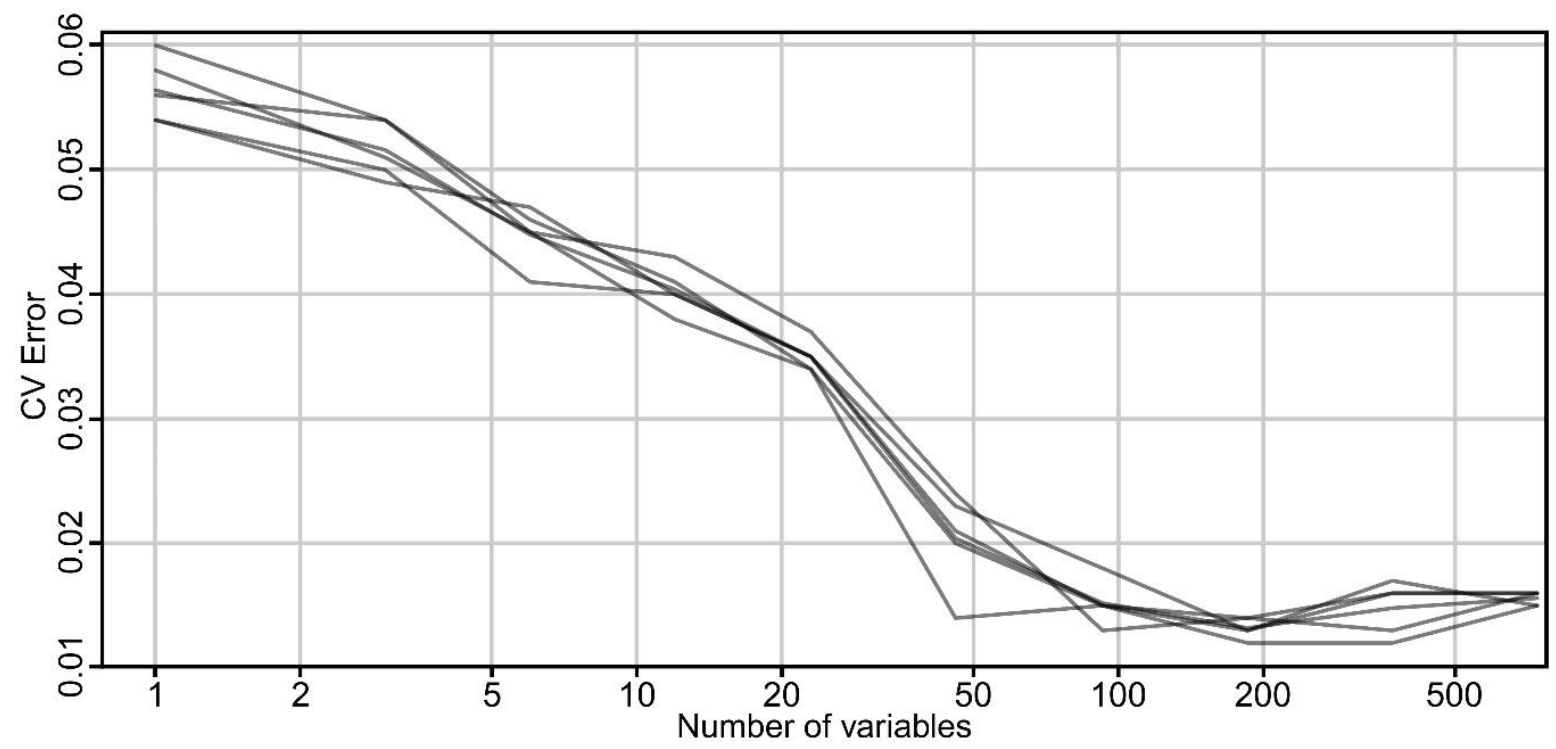

Figure 9. Plot of $\mathrm{CV}$ error of 5 replicates for 10 -folds $\mathrm{rfcV}$ with all the variables. https://doi.org/10.6084/m9.figshare.11798658

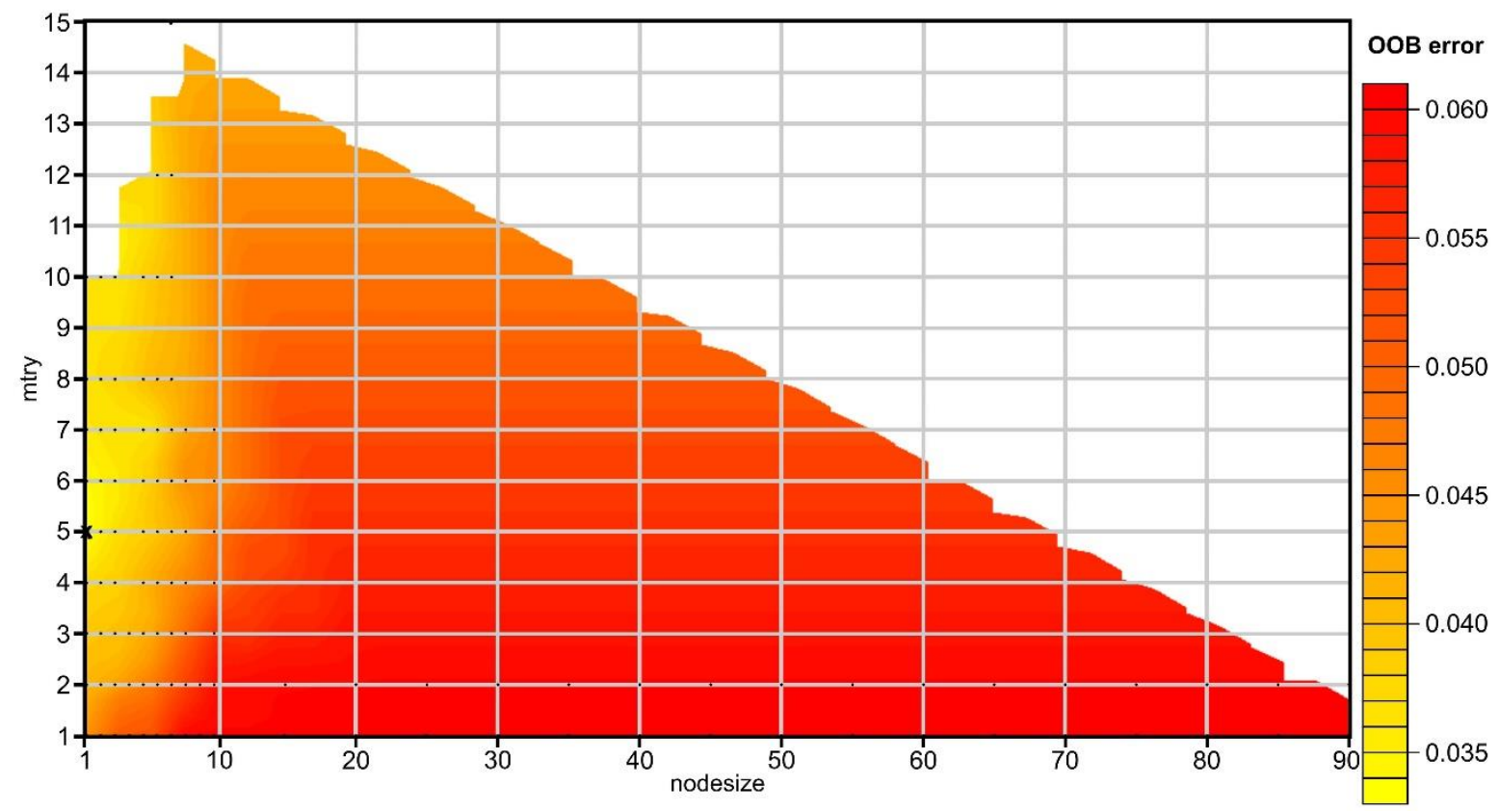

Figure 10. Plot of $\mathrm{OOB}$ error showing the mtry and nodesize tuning with 100 ntree. https://doi.org/10.6084/m9.figshare.11798661

Even at 1000 segments training dataset, 100 ntrees are enough for good results. I believe that this is happening at so low number of trees because of the class imbalance, which is resolved with a small number of very deep trees. Regarding the variables that give the best confusion matrix results I applied an iterative approach in which each variable was tested for the number of true positives and false positives and through this procedure the shape descriptors and the descriptive statistics of the altitude (referenced as dem in Figures 11 and 12) and index of convergence (ioc) have given the best results, being used in fitting the final model. The list of the 72 used geomorphometric variables and shape descriptors is given in Table S2.

Investigating the minimal depth of the trees for each variable and its mean (Figure 11) we can see the variables which are the most predictive (the smallest mean value of minimal depth) in terms of tree topologies. From the 20 variables plotted in Figure 11 we can see that elevation standard deviation, $90^{\text {th }}$ quartile of ioc and elevation range have the longest trees and are always used to split trees at the root. The RF model constructed 100 trees and no limit to the maximum number of terminal 
nodes trees in a tree was setup, in Figure 11 legend being visible that trees were split until depth of 28.

Variable importance is given by the difference in OBB error between the situation when only the variable is perturbed and when is not, for that tree. In Figure 12 we can see plotted all the variables used, as a relation between accuracy decrease (if that variable is perturbed) and the number of node splits for that variable, the size of the circle indicating the number of times that the variable is a root. The blue colored circles correspond to the first 10 important variables. We can see again here variables which are also predictive, and have presence as number of nodes and times a root. There is a clear relation between the accuracy decrease and number of nodes (as the number of nodes decrease the accuracy is not so decreased), but there are also not so important variables (by accuracy decrease, mainly index of convergence percentiles), with a small number of nodes but used many times as a root. This situation shows that using these variables in the model, and not removing them, although will increase the OBB error, will allow the model to increase the true positives and decrease the false positives (Table 1).

The variable interactions (in pairs of one by one) are given by the splits that appear in maximal subtrees in regard with the variables, and can be assessed by computing the mean conditional minimal depth (a variable is taken as root/node and the mean minimal depth is computed for the other variable) versus mean unconditional minimal depth (the overall mean minimal depth shown in Figure 11).

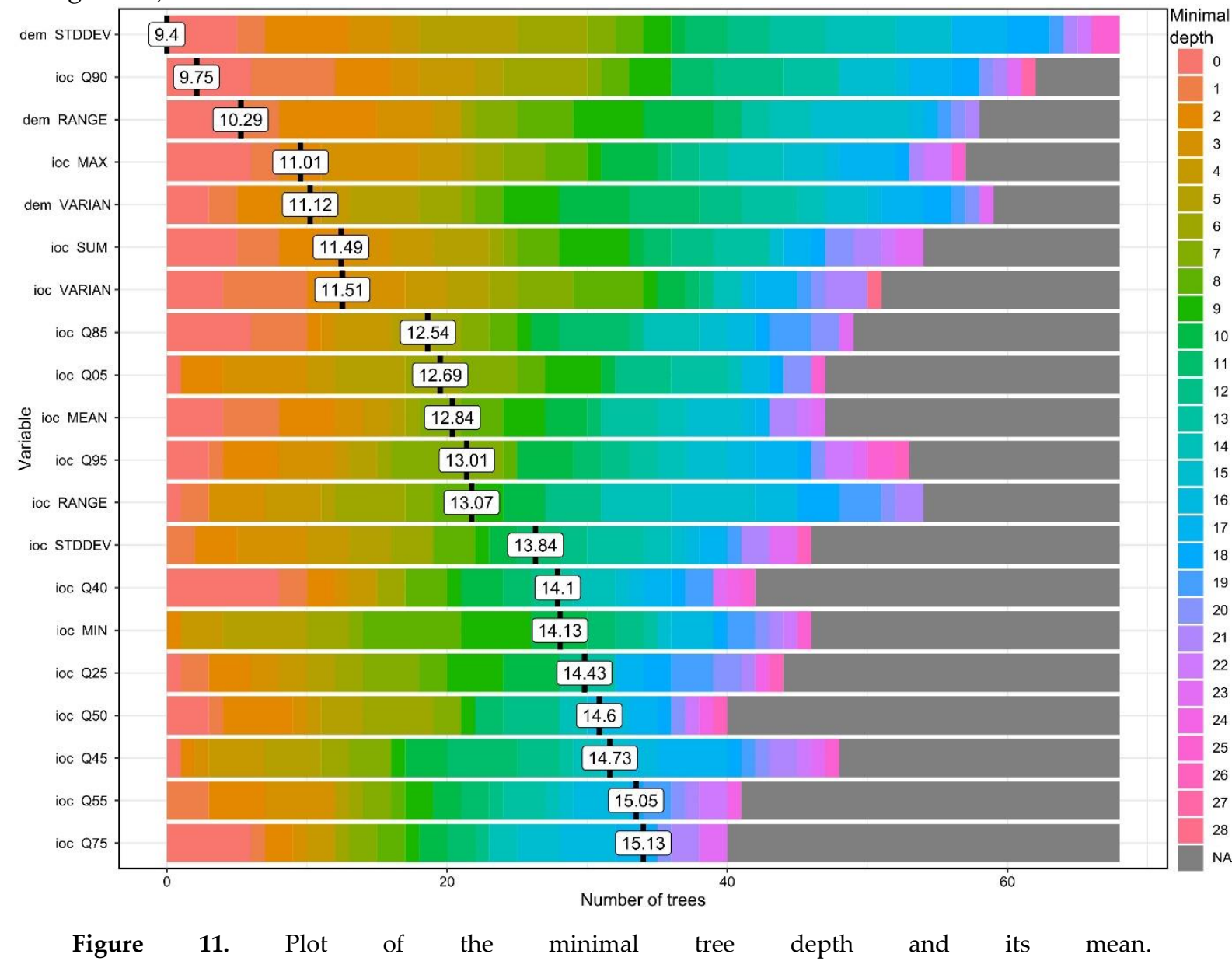

https://doi.org/10.6084/m9.figshare.11798667.v1

In Figure 13 I show the 30 most frequent interactions of the first 5 most important variables sorted by the decreasing number of occurrences (color of the bar), the bar showing the mean conditional minimal depth and the line the unconditional mean minimal depth. Standard deviation of altitude has the biggest occurrence and the unconditional mean minimal depth of it in the forest is almost equal with its mean minimal depth across maximal subtrees. Beside altitude standard 
deviation, range and variance which are measures of local peak amplitude, index of convergence measures (maximum and percentiles) define convex features that have local prominence. Shape descriptors appear to be used for node splitting and interacting with the previous variables at a certain point, the following being used: ratio between diameter and square root of area (a measure of similarity to a square, since square root of area is the side length), Feret diameter measured at an angle of $90^{\circ}$ to that of the maximum Feret diameter, and shape index.

In Figures 14 and 15 it can be seen that the feature space of burial mound segments it very well defined especially for the most important variables. By the examination of the descriptive statistics (Figure 16) for the two segment classes of the 8 important variables and three variables that were rejected (non-burial and burial), it can be observed that all of them show statistic significant differences between the classes. This situation shows that the selection of the variables can be done based on expert opinion but the only by iterative tuning the variables that give the best results can be chosen.

In the literature, several approaches are used for training and testing: (i) retaining random $50 \%$ for training and validating on the other $50 \%$, (ii) using random $75 \%$ for training and the rest $25 \%$ for testing, (iii) using cross-validation or (iv) using stratified sampling. The latin hypercube sampling method was chosen for sampling for the training dataset, to supplement for the class imbalance. It can be seen in Figure 15 how does the training dataset is distributed compared with the validation area. I tested three burial-mounds class frequencies (50\%, 75\%, 100\%) within the training sample. The validation was performed internally on the whole northern dataset (Figure 17 and Table 1) and externally on the whole southern dataset (Figure 18 and Table 1).

As the frequency of burial mound class from the training sample decrease, the precision increase due to fewer false positives, but because the false negative cases also increase, the sensitivity (SNS) and accuracy (ACC) degrades, nonetheless $36 \%$ of the burial mounds for southern study area being missed. If the frequency of burial mound class from the training sample increase, the false positive cases will increase, but also the false negative cases decrease, situations when although the accuracy is lower, only $9 \%$ of burial mounds will be missed. In this situation there will be 56 segments to be checked in order to find the $82 \%$ predicted burial mounds. 


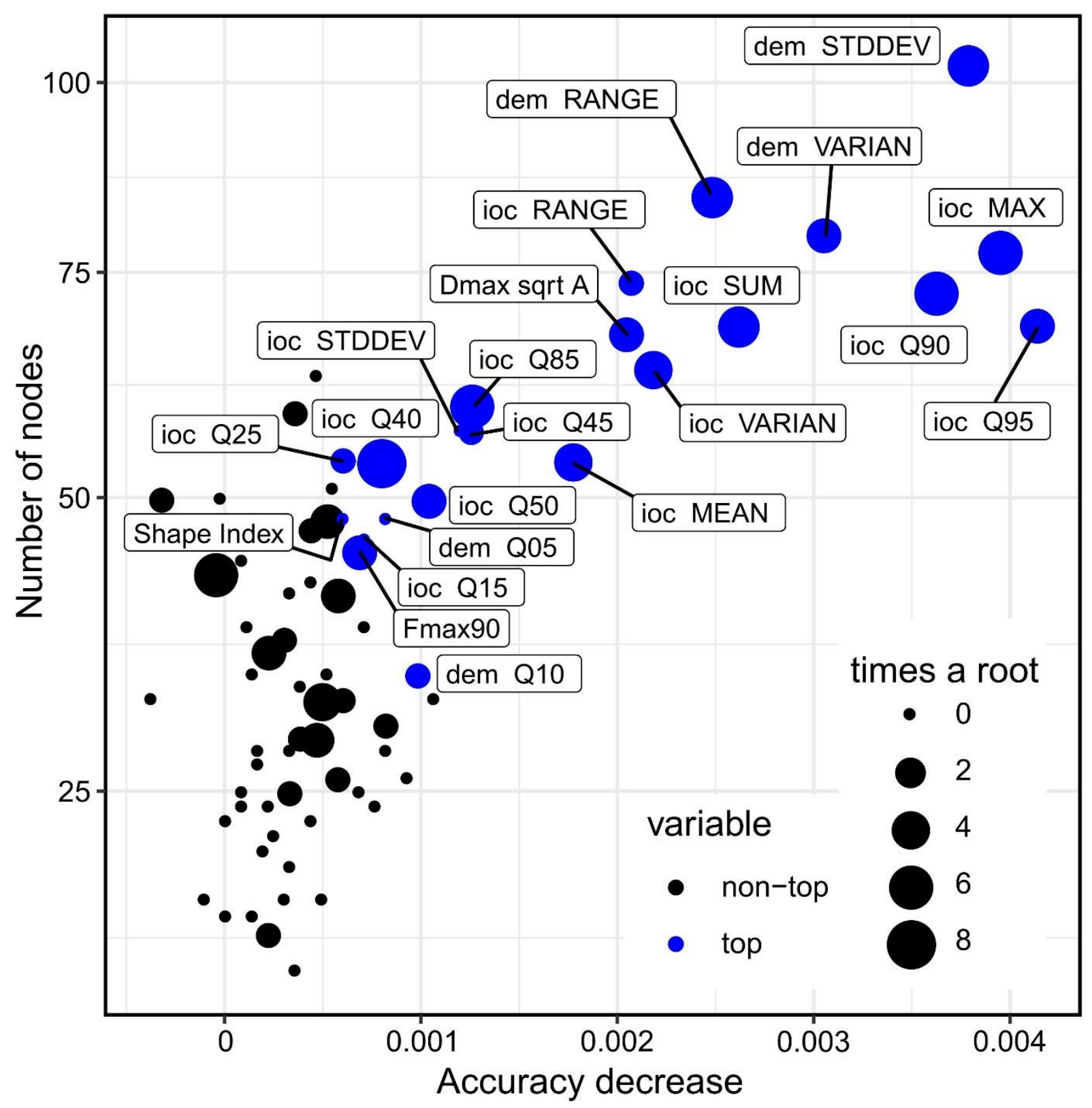

Figure 12. Plot of OOB error showing the mtry and nodesize tuning with 100 ntree. https://doi.org/10.6084/m9.figshare.11798673.v1

The situation needs to be resolved through a trade-off between how many false positive are enough in order to have the biggest number of true positives. In this regard, depending on the physiographic and anthropic characteristic of the studied area, many non-burial mounds candidates can be filtered if there is knowledge that burial mounds were not built there (like under the forest, under built, rocky or swampy areas). The rest of the false positives needs to be checked in order to reveal the true positives. Even in this situation, if these segments are clustered (as in the case of the present study, see Figures 17 and 18) the task might not be very time consuming and can be semiautomatized. 
19 of 33

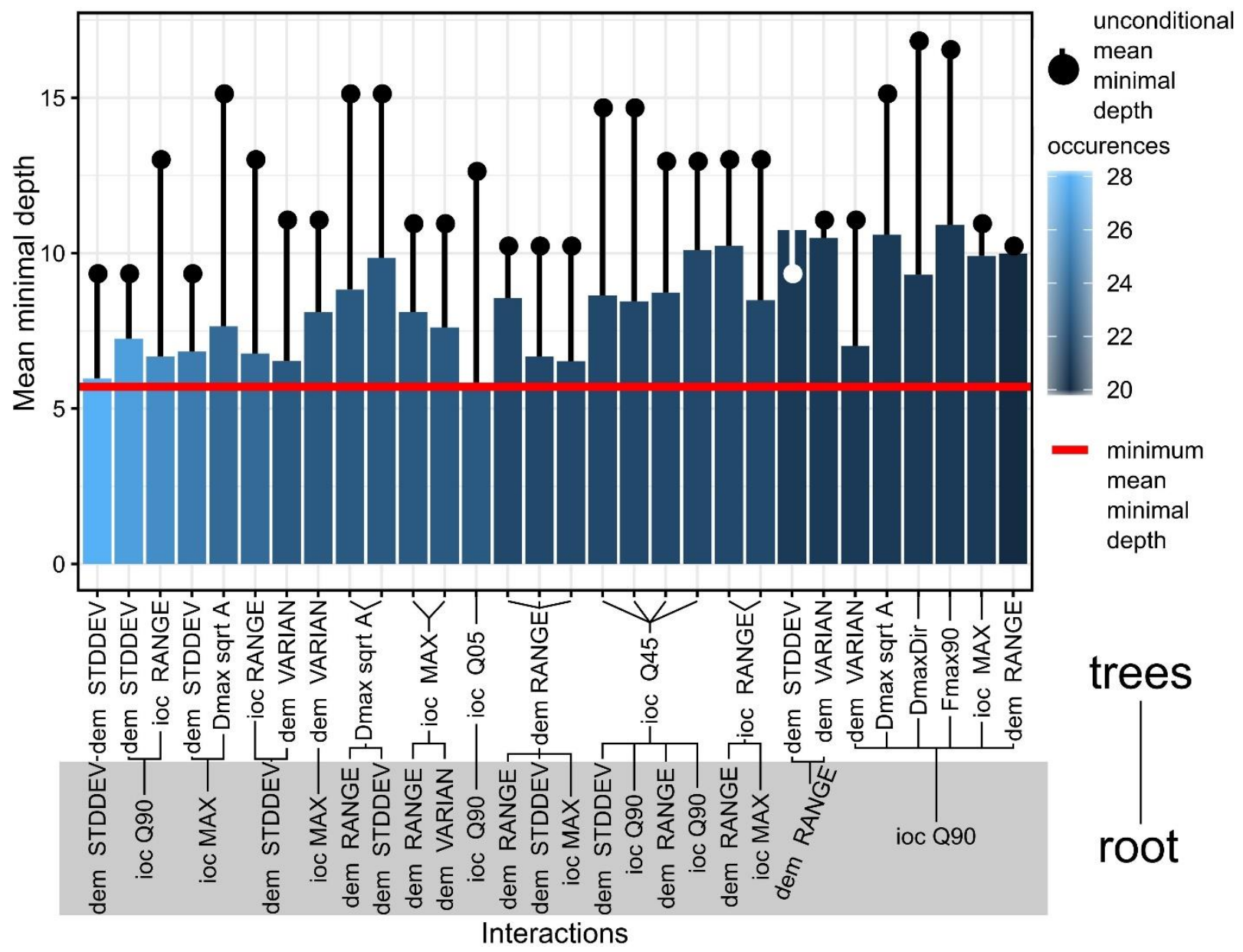

Figure 13. Mean minimal depth for 30 most frequent interactions. https://doi.org/10.6084/m9.figshare.11798679

Table 1. The RF model parameters and the confusion matrix of the validation results.

\begin{tabular}{|c|c|c|c|c|c|c|c|c|c|c|c|c|c|c|}
\hline \multirow[t]{2}{*}{ No } & \multirow{2}{*}{$\begin{array}{c}\text { Size of } \\
\text { training } \\
\text { dataset }\end{array}$} & \multirow{2}{*}{$\begin{array}{l}\% \text { burial } \\
\text { mounds }\end{array}$} & \multirow{2}{*}{$\begin{array}{l}\text { OBB } \\
\text { error }\end{array}$} & \multicolumn{4}{|c|}{$\begin{array}{c}\text { Northern study area } \\
\text { confusion matrix }\end{array}$} & \multicolumn{7}{|c|}{$\begin{array}{c}\text { Southern study area } \\
\text { confusion matrix and measures }\end{array}$} \\
\hline & & & & TP & TN & FP & FN & TP & TN & FP & FN & SNS & FPR & ACC \\
\hline 1 & 2000 & 50 & 1.5 & 54 & 12670 & 11 & 10 & 16 & 10572 & 10 & 11 & 0.59 & 0.001 & 1.00 \\
\hline 2 & 2000 & 75 & 2.0 & 61 & 12669 & 12 & 3 & 20 & 10571 & 11 & 7 & 0.74 & 0.001 & 1.00 \\
\hline 3 & 2000 & 100 & 1.8 & 64 & 12668 & 13 & 0 & 21 & 10565 & 17 & 1 & 0.95 & 0.002 & 1.00 \\
\hline 4 & 1000 & 50 & 3.3 & 51 & 12663 & 18 & 13 & 17 & 10558 & 24 & 10 & 0.63 & 0.002 & 1.00 \\
\hline 5 & 1000 & 75 & 3.1 & 63 & 12629 & 52 & 1 & 25 & 10536 & 46 & 2 & 0.93 & 0.004 & 1.00 \\
\hline 6 & 1000 & 100 & 3.1 & 64 & 12634 & 47 & 0 & 25 & 10540 & 42 & 2 & 0.93 & 0.004 & 1.00 \\
\hline 7 & 500 & 50 & 5.2 & 53 & 12562 & 119 & 11 & 19 & 10487 & 95 & 8 & 0.7 & 0.009 & 0.99 \\
\hline 8 & 500 & 75 & 4.6 & 63 & 12502 & 179 & 1 & 25 & 10382 & 200 & 2 & 0.93 & 0.019 & 0.98 \\
\hline 9 & 500 & 100 & 3.8 & 64 & 12424 & 257 & 0 & 26 & 10279 & 303 & 1 & 0.96 & 0.029 & 0.97 \\
\hline 10 & 100 & 50 & 10 & 64 & 11337 & 1344 & 0 & 27 & 9635 & 947 & 0 & 1.00 & 0.089 & 0.91 \\
\hline 11 & 100 & 75 & 9 & 64 & 11366 & 1315 & 0 & 27 & 9662 & 920 & 0 & 1.00 & 0.087 & 0.91 \\
\hline 12 & 100 & 100 & 6 & 64 & 10119 & 2562 & 0 & 27 & 8953 & 1629 & 0 & 1.00 & 0.154 & 0.85 \\
\hline
\end{tabular}



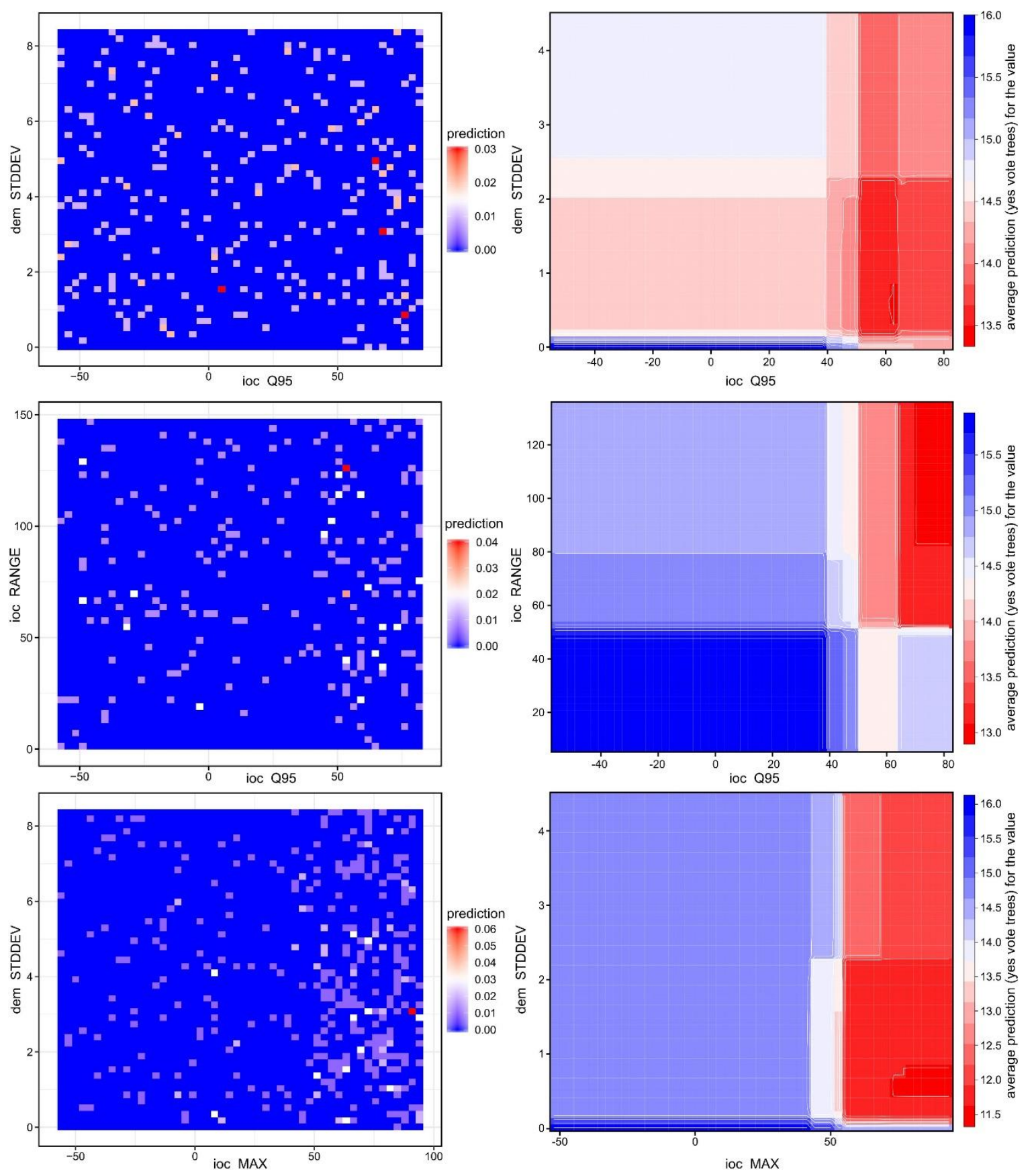

Figure 14. Prediction plots (left) and partial dependence plots (right) for the most three important variables. https://doi.org/10.6084/m9.figshare.11798682.v1 

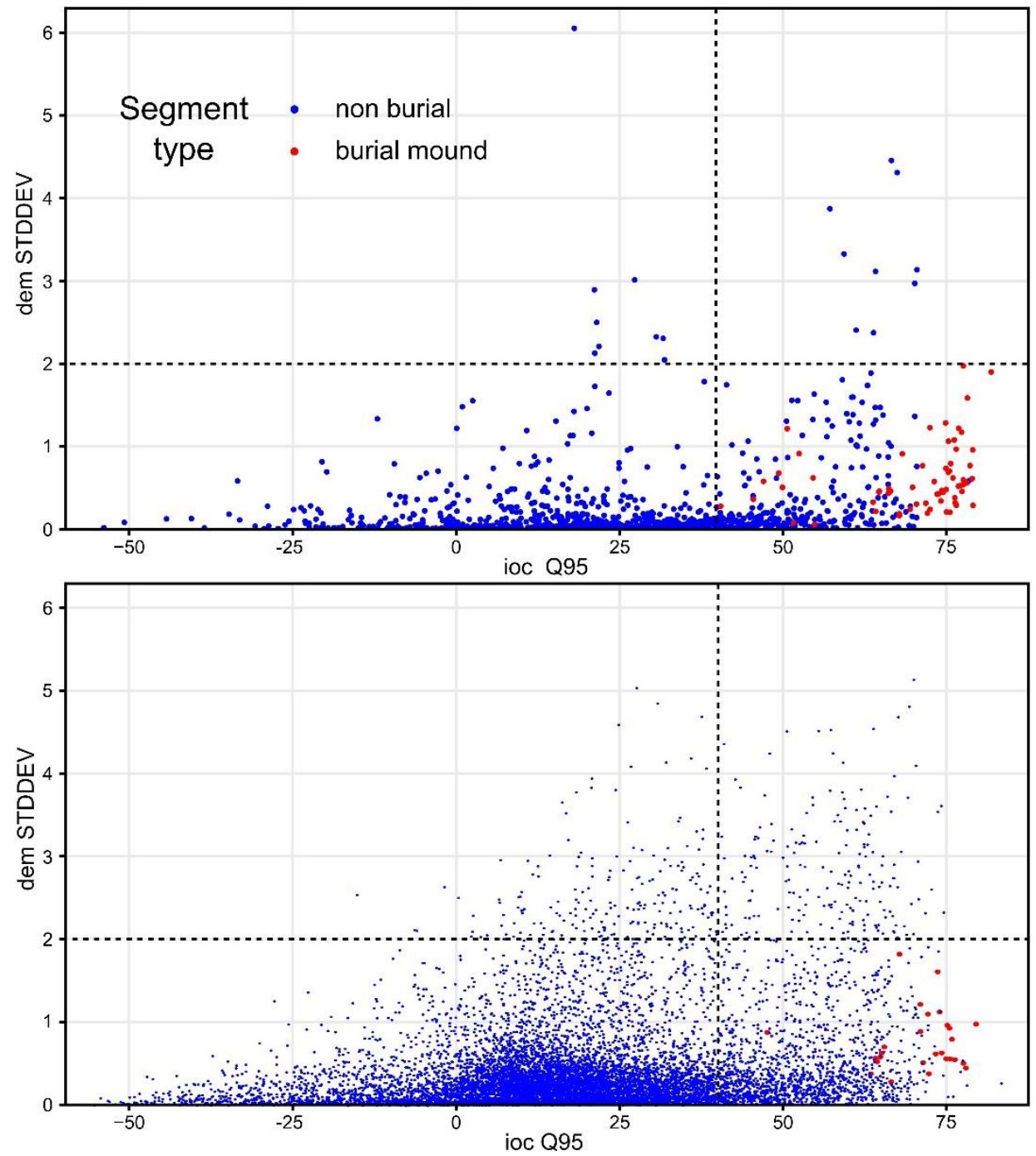

Figure 15. The training (left) and the validation (right) datasets distribution in the feature space of the two most important variables. https://doi.org/10.6084/m9.figshare.11798688.v1
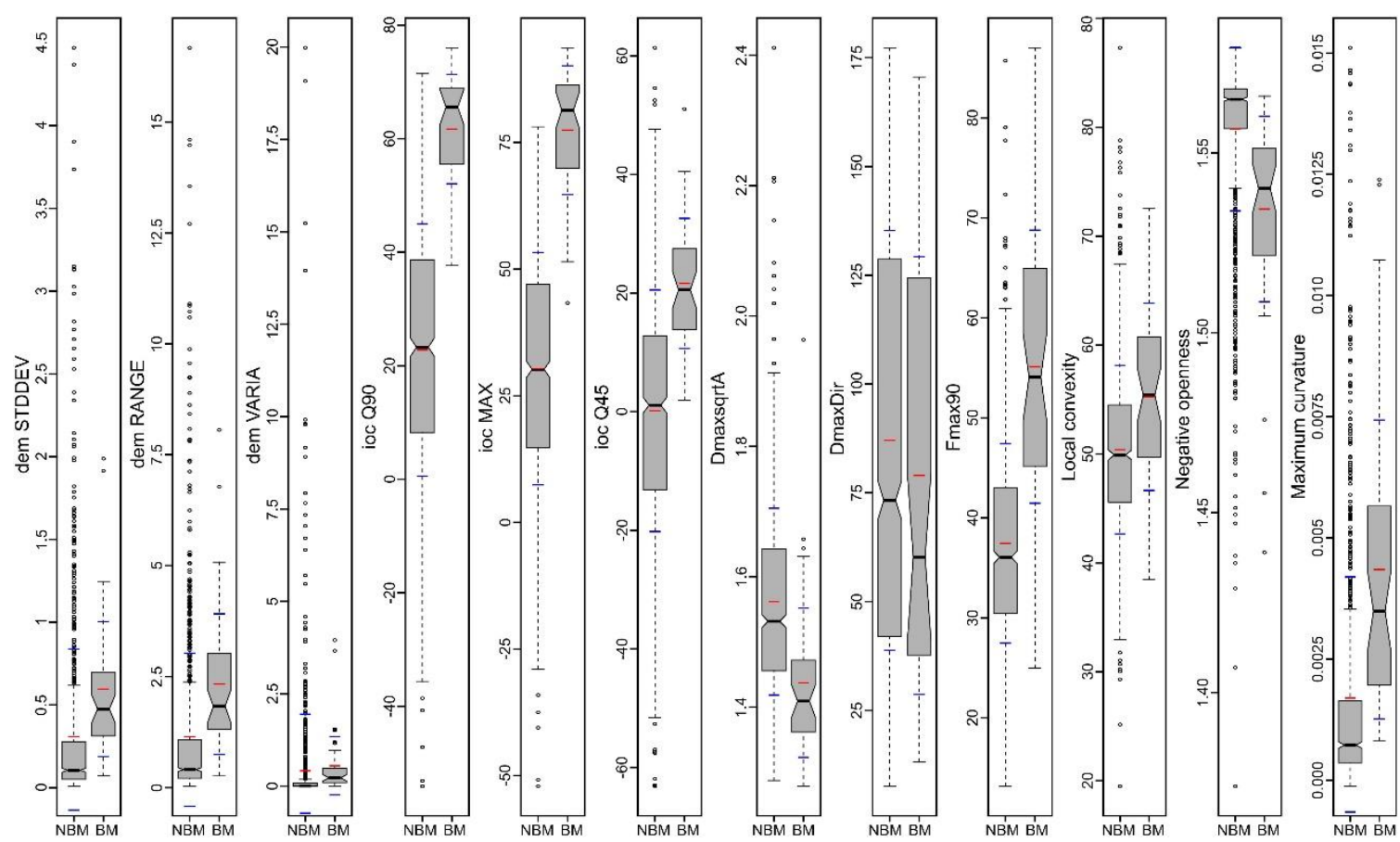
Figure 16. The descriptive statistics of the non-burial mound (NBM) and burial mound (BM) segments for the most important variables and for some variables that were not selected for fitting the RF model (local convexity, negative openness and maximum curvature). https://doi.org/10.6084/m9.figshare.11798691.v1

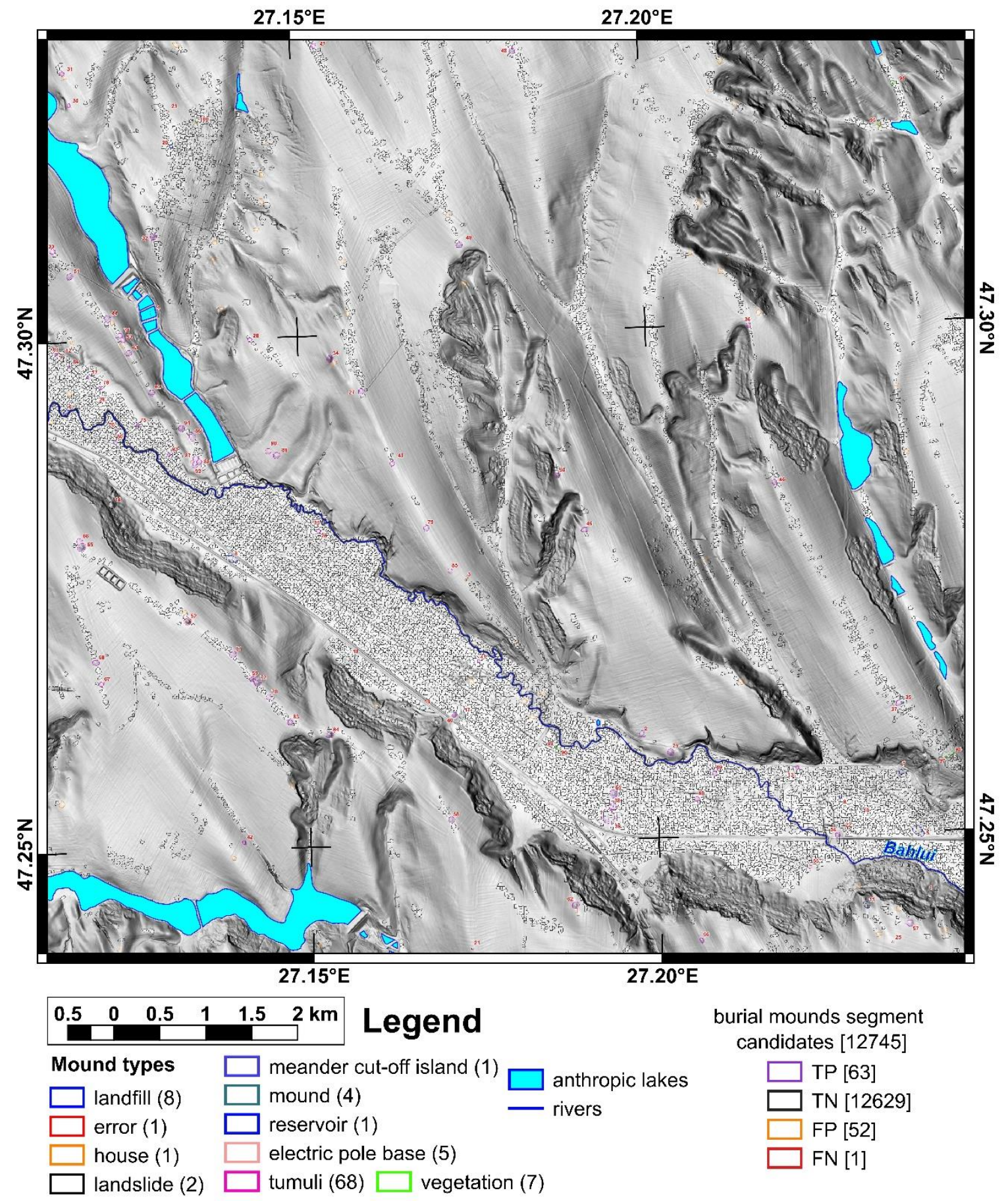

Figure 17. The burial mounds local convexity watershed segments candidates for the northern study area. https://doi.org/10.6084/m9.figshare.11798694.v2

\subsection{Burial mounds delineation}

Watershed segmentation is able to identify local maxima as seed points and grow the region around until a certain threshold is meet. This approach delineates well the convex feature of the mounds and is used in conjunction with the selected peaks to select segments as candidates for burial mounds. The majority of the burial mounds have local convexity segments centered around the peak, 
for validation purposes the centroid of the burial mound being used to identify the association between segments and burial mounds. Only burial mounds that have geomorphometric similarity with shoulders fail to have a centered segment (for example burial mound 23 from the southern study area).

For the spatial extension of the burial mounds, the local convexity watershed segmentation works better in its interpolated approach (Figure $6 a$ and b). It can be seen in Figure $6 a$, b, e and f, that the cell count method watershed segment continues beyond the basal edge of the burial mounds, along the local ridge. The watershed segments computed with the resampling cell count method delineates pretty well the burial mounds. In Figure 19 it can be seen that this is due to the values of local convexity maxima and minima. While the cell count method gives 100\% local convexity around the mound peak, the cell count resampling only gives a maxima of $97 \%$. The minima values are repetitive along the mound border for the cell count method (Figure 6 a, the western boundary of the mound) and the watershed algorithm does not close the segment, while for the cell count resampling have a variation that is enough for the watershed algorithm to close the segment.

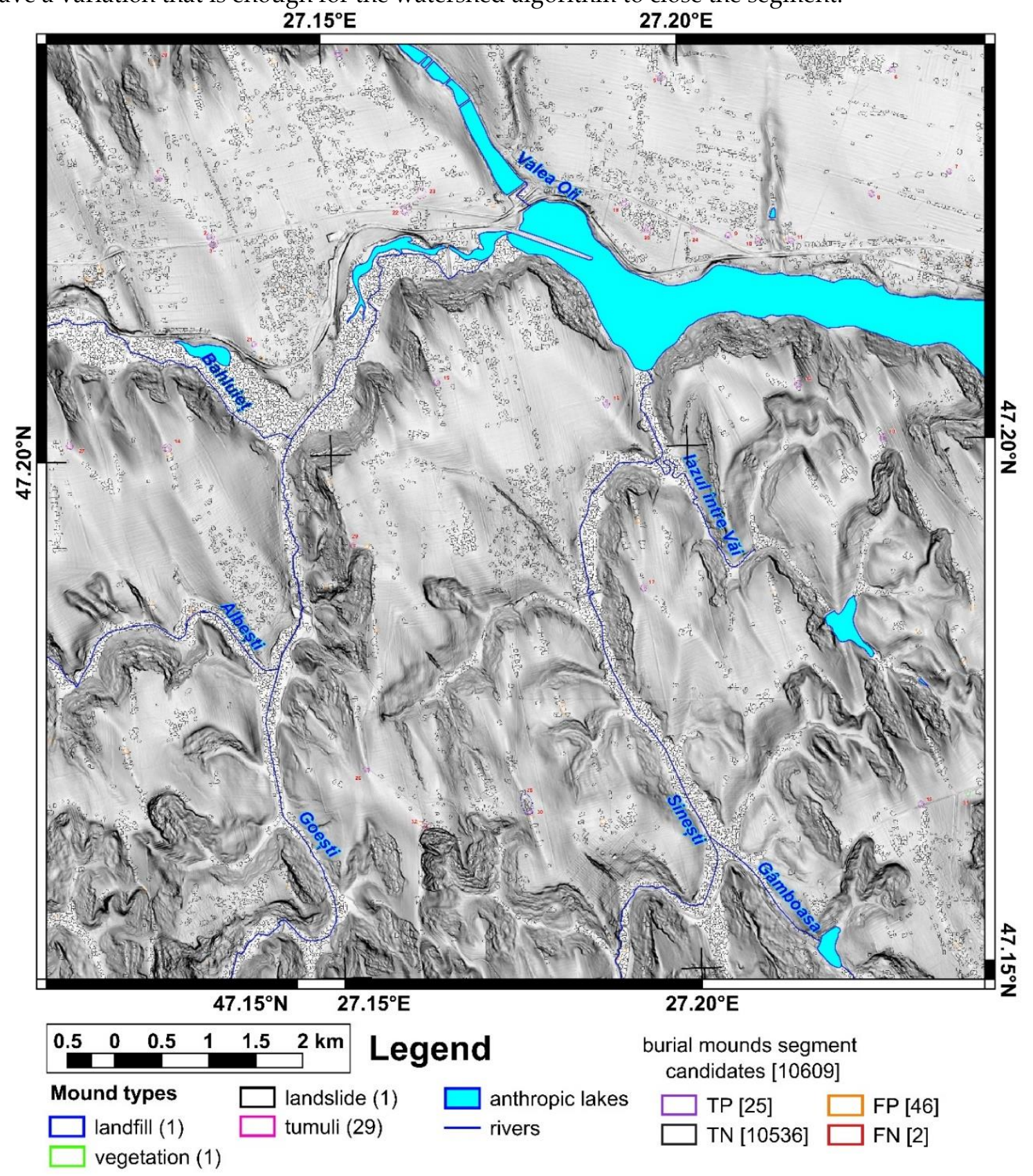

Figure 18. The burial mounds local convexity watershed segments candidates for the validation (southern) study area. https://doi.org/10.6084/m9.figshare.11798697.v1 
In order to estimate the accuracy of the watershed segmentation regarding the mound delineation, I used the area of the intersection of watershed segment with the burial mounds manual delineation.

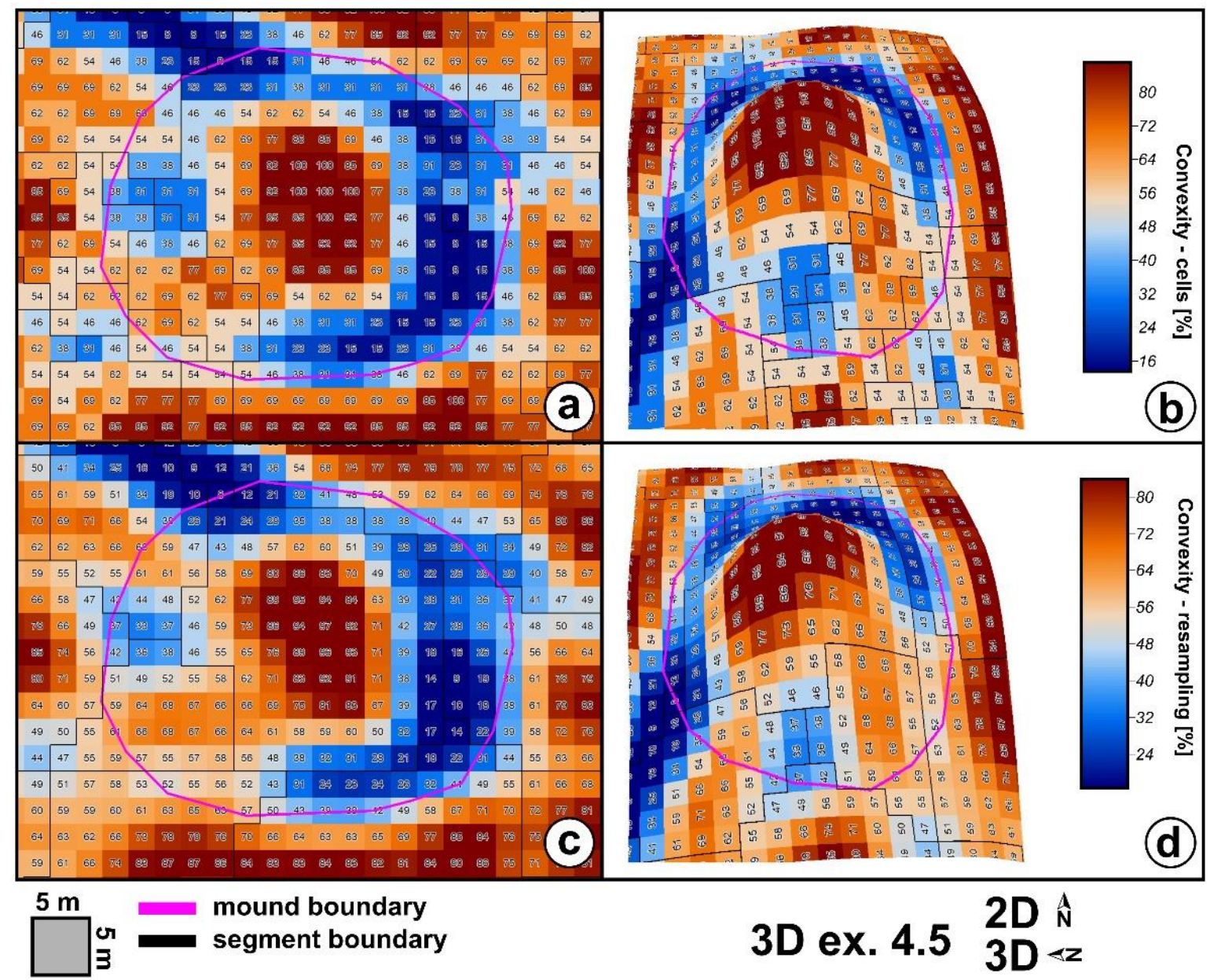

Figure 19. The burial mound watershed delineation based on both methods of local convexity computation: a (2D) and b (3D) for cell count method, and c (2D) and d (3D) for the cell count interpolation method. https://doi.org/10.6084/m9.figshare.11798700.v1

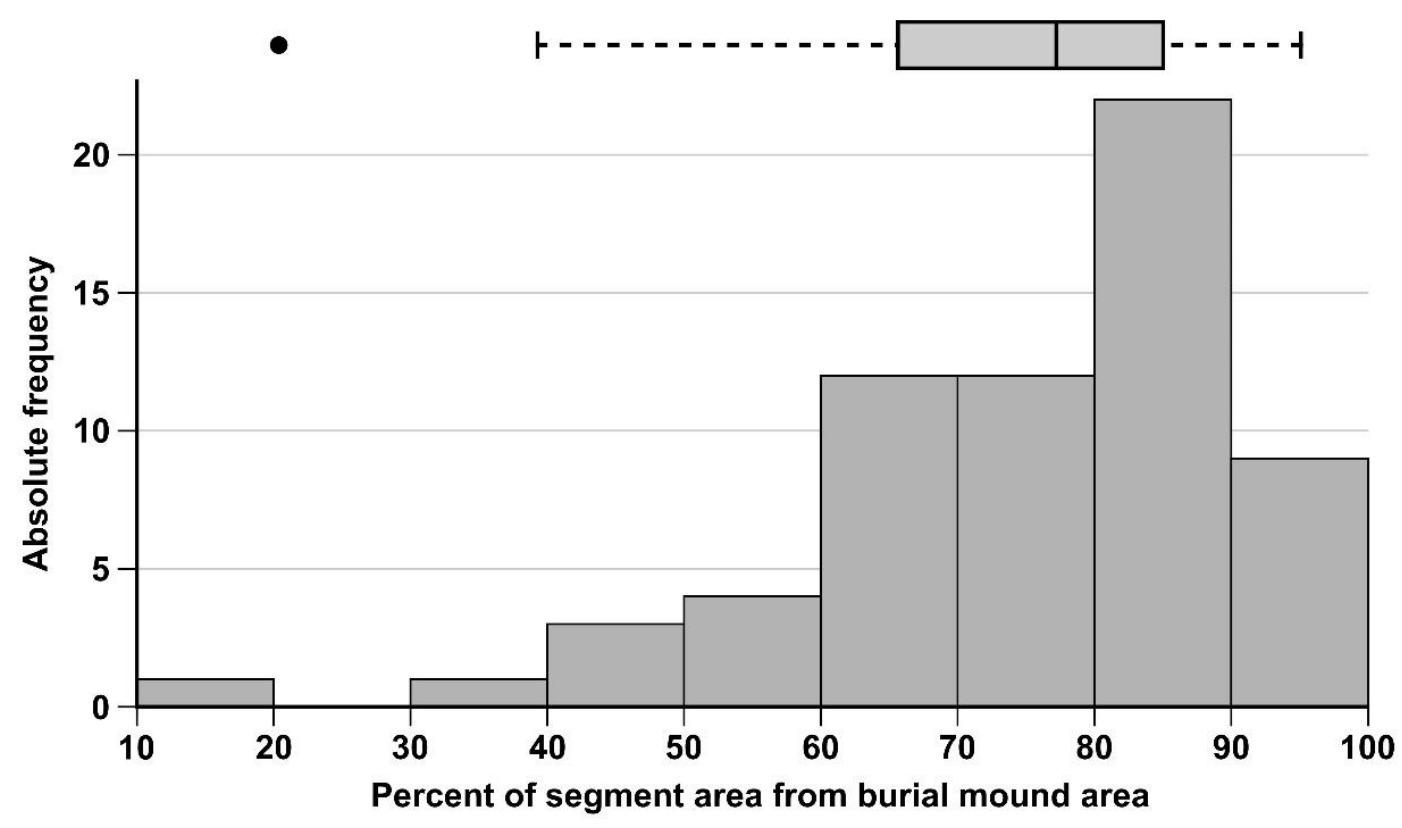


Figure 20. The accuracy statistics of the watershed segmentation for the northern study area. https://doi.org/10.6084/m9.figshare.11798703.v1

This area was reported as percent from the manually delineated burial mounds area. The results for the northern dataset are shown in Figure 20. The distribution if skewed to the right, with only three values under $50 \%$, a mean of $75 \%$ and a median of $79 \%$ (burial mounds 39 and 38 from the northern study area - Figure 17, having the smallest segment proportions). The watershed segmentation identifies very well the convex area of the burial mounds, but not so well the basal part which is concave.

\section{Discussions}

The proposed method for burial mound identification from high-resolution LiDAR DEM works in three steps. In step one local peaks are identified and the algorithm missed two burial mounds that due to smoothing do not have peaks (burial mound 85 and 90 from Figure 1, S9 and S10). These two burial mounds are located on inclined hillslopes and due to smoothing, do not preserve the peak, which is rather a shoulder (as the topographic cross-section in S9 and S10 clearly show). The situation repeats for a landslide body mound which was mapped (mound 14 from Figure 1). In the southern study area from 29 burial mounds, 1 burial mound (burial mound 24 from Figure 2, S12) has the same smoothed appearance, being located on gentle inclined hillslopes and having a shoulder shape. Burial mound 24 has its morphology also affected by a road cut.

The peak selection missed another two burial mounds. (burial mounds 55 and 76 from Figure 1, S6 and S8). Burial mound 55 is located on a low steepness (glacis) surface between the Bahlui valley hillslope and its floodplain, has approx. $40 \mathrm{~m}$ in diameter and is smoothed ( $\sim .75 \mathrm{~m}$ in height). Burial mound 76 is located on a furrow ridge on the Bahlui floodplain, has approx. $30 \mathrm{~m}$ in diameter and is smoothed ( $0.75 \mathrm{~m}$ in height). Both burial mounds have peaks but not seeds, so not selected peaks. It can be concluded that these burial mounds are missed due to low height because are smoothed by tillage. Another landslide mound (with ID 1 from Figure 1 and S1) which has a peak, but not a local convexity seed in proximity. In the southern study area burial mound 23 does not have a selected peak that corresponds to local convexity segment. Its height is $\sim 0.6 \mathrm{~m}$ and selected peaks are located on the northern part, but correspond to segments too small to be included in the burial mound centroid. The shape of this mound is very similar to a shoulder.

The two steps have an accuracy of $96 \%$ in identifying the burial mounds. The RF classification was able to find all the remaining 64 burial mounds trained with all the burial mound segments and 63 burial mounds trained with $75 \%$ of the burial mound segments; 47 and 52 false positive burial mounds were also found (Figure 17). The validation of the method in the southern study area, of the same size and where 25 burial mounds were selected shows a sensitivity of 0.93 (Table 1), with the tradeoff that 42 and 46 false positive burial mounds were also found.

For the northern study area burial mound 52 fails to be identified as burial mound. This burial mound has geomorphometric characteristics above the mean, but is not the highest or the biggest. Its detection failure in the scenario of $75 \%$ burial mound segments used for training of RF, can be associated with its very concave border, that generated a higher dispersion of the index of convergence statistics.

For the southern study area burial mounds 29 and 32 (Figure 2, 18, S14) failed to be identified. Burial mound 29 is located at the edge of the ridge, a part of it being affected by a landslide scarp, situation that was already identified in the study area [63] as characteristic for certain burial mound locations. This position, makes the corresponding segment geomorphometric characteristics to be different than of the burial mound segments used for training, which are located on flat or gentle slope surface. Burial mound 32 has its morphology degraded by a road cut and by anthropic excavations, deviating from the geomorphometric signature of burial mounds.

The present approach is different from the ones existing in the literature until now $[37,39]$ because it uses both supervised and unsupervised methods, and both pixels and objects. I believe that the use of template matching [17] methods or convolutional neural networks [15] in our case is 
restricted by: (i) the big area of study $\left(100 \mathrm{~km}^{2}\right)$ with an uneven repartition of burial mounds and the bigger area which should be investigated in the future (the whole Moldavian Plateau, approx. 19000 $\mathrm{km}^{2}$ ). The use of other supervised classification algorithms [39] has the same limitations given by the size of the area. The use of pixel-based variables and geomorphometric objects reduce the computational load and simplify the detection approach.

The usage of a DEM at $5 \mathrm{~m}$ resolution, is argued for obtaining shorter run times on normal PCs and for applying the methodology on extended areas. At $5 \mathrm{~m}$ spatial resolution the shape of burial mounds is well represented, and a $5 \times 5$ pixels windows fits the smallest burial mound (Figure 7). It is to be expected that the methodology could be used at lower or higher spatial resolutions, if the burial mounds have different diameters, but at different spatial resolution the present RF model is unusable, a new RF needs to be fitted again, since the scale of the segments will change and the morphometric signature of the burial mounds is different.

Since the problem, from a statistical point of view is a binary one, actually the overall accuracy is not necessarily a good measure in practice, but the measures of different types of errors need to be studied. Beside true positives, also false positives are of interest, that is why sensitivity and false positive rate measures of the confusion matrix are the most informative regarding the power of the proposed method. Since, the shape of the burial mounds is not always the initial one (the height and the diameter have a large range of variation), due to erosion, many false positive cases are found. These false positive cases appear due to similarities in geomorphometry of the burial mounds and of rugged landform facets. The selected segments shown in Figures 17 and 18 are located on floodplains, hillslopes and ridges, in areas where there is a certain convexity, very often in relation with human induced topography: road embankments, furrows. In this situation, the RF algorithms is able to classify the burial mounds with good accuracy, but at the cost of finding also false positives. Lowering the false positive cases is possible, but comes with a loss of almost $50 \%$ of the true positives.

Compared to the approach of [36] which appears to be the single one in the literature where the study area is large but where there is no specification in which area the accuracy was computed, our approach performs better in terms of accuracy by identifying almost all the mapped burial mounds (Table 1). Compared to the list compiled by [15] our results rank the proposed method as the second, after the one of [41] in terms of confusion matrix accuracy. Unfortunately [41] does not specify exactly what was the reference dataset, and present a confusion matrix that add up to 25165 pixels, clearly only a subset of the study area, without specifying which was the validation area. In this context it is hard to compare the two methods. Even the usage of pixels instead of objects is problematic, since the use of a confusion matrix indices is biased by the selection of true positive pixels. Beside the accuracy, which is an overall measure, important are the numbers of false positive cases, that need to be checked by manual intervention for the selection of the burial mounds. In our case, the predicted polygons can be automatically mapped on LiDAR DEMs shading and presented to an operator for a final validation.

Further steps that can improve the method and its applicability will be the testing for the entire Moldavian Plateau, for other areas, where different types of burial mounds and with different spatial scales are present. Since the proposed algorithm can be implemented in open source software, it can be run in a tiled scheme for big areas on high to medium resolution data (1 to $5 \mathrm{~m}$ ) and on PCs (4 to 8 cores and 10 to $24 \mathrm{~GB}$ of memory). Also, the testing of other geomorphometric variables and other automatic segmentation approaches could derive better mapping of burial mound candidates. The proposed approach statistical classification method could also be changed.

\section{Conclusions}

The proposed method based on geomorphometric processing of LiDAR data is able to identify the peaks of burial mounds and to extract with high accuracy their upper part, which is the bestpreserved area of the initial burial mound surface. The accuracy of the proposed method is one of the best reported in literature. The use of geomorphometrical objects (peaks and segments), reduce the feature space of the classifications approach, which is a highly imbalanced. Burial mounds are very similar in geomorphometry with other anthropic and natural mounds. The use of RF approach for 
the final classification step proved to give satisfactory results, since RF is able to resolve the imbalance class problem and the geomorphometric convergence. RF is able to depict slight geomorphometric signatures that differentiates the burial mounds from other mounds.

Sensitivity of 0.93 and false positive rates of 0.004 are achievable with RF tuning and variable selection, which I recommend for every statistical classification approach. The OBB error is not necessarily a good measure of model performance on the validation dataset, the confusion matrix measures giving the final answer. A good balance between false and true positives needs to be achieved. Nevertheless, a big number of false positives show that the results need to be checked by an operator. The searching area is limited to $\sim 1 \%$ of the study areas, which is a big improvement compared to a raw search approach. The presented method has the potential to be used on wide areas in order to identify the presence of burial mounds, as is the case of the Moldavian Plateau, and should be tested against other methods and tested on other geomorphometric and archaeologic settings.

Supplementary Materials: The following are available online: Figures S1-S9: Burial mounds and other types of mound for the northern study area (https://doi.org/10.6084/m9.figshare.11798715.v1, https://doi.org/10.6084/m9.figshare.11798733.v1, https://doi.org/10.6084/m9.figshare.11798757.v1, https://doi.org/10.6084/m9.figshare.11798766.v1, https://doi.org/10.6084/m9.figshare.11798775.v1, https://doi.org/10.6084/m9.figshare.11798802.v1, https://doi.org/10.6084/m9.figshare.11798811.v1 https://doi.org/10.6084/m9.figshare.11798814.v1， https://doi.org/10.6084/m9.figshare.11798817.v1, https://doi.org/10.6084/m9.figshare.11798820.v1), Figures S10-14: Burial mounds and other types of mound for the southern study area (https://doi.org/10.6084/m9.figshare.11798823.v1, https://doi.org/10.6084/m9.figshare.11798826.v1, https://doi.org/10.6084/m9.figshare.11798832.v1, https://doi.org/10.6084/m9.figshare.11798835.v1), Table S1: The list of geomorphometrical variables and their computation settings in SAGA GIS, Table S2: The list of the geomorphometrical variables and shape descriptors used for fitting the RF model.

Funding: This work was supported by a grant of the "Alexandru Ioan Cuza" University of Iași, within the Research Grants program, Grant UAIC, code GI-UAIC-2017-07.

Acknowledgments: I am grateful to Prut-Bârlad Water Administration who provided us with the LIDAR data. I would like to thank the two anonymous reviewers for their thoughtful comments and efforts towards improving our manuscript. I would also like to deeply acknowledge PhD student Valeriu Stoilov-Linu for the help with the fieldwork.

Conflicts of Interest: "The authors declare no conflict of interest."

\section{References}

1. Ackermann, F. Airborne laser scanning-present status and future expectations. ISPRS Journal of Photogrammetry and Remote Sensing 1999, 54, 64-67, doi:10.1016/s0924-2716(99)00009-x.

2. Axelsson, P. Processing of laser scanner data-algorithms and applications. ISPRS Journal of Photogrammetry and Remote Sensing 1999, 54, 138-147, doi:10.1016/s0924-2716(99)00008-8.

3. Baltsavias, E.P. A comparison between photogrammetry and laser scanning. ISPRS Journal of Photogrammetry and Remote Sensing 1999, 54, 83-94, doi:10.1016/s0924-2716(99)00014-3.

4. Wehr, A.; Lohr, U. Airborne laser scanning-an introduction and overview. ISPRS Journal of Photogrammetry and Remote Sensing 1999, 54, 68-82, doi:10.1016/s0924-2716(99)00011-8.

5. Tarolli, P. High-resolution topography for understanding Earth surface processes: Opportunities and challenges. Geomorphology 2014, 216, 295-312, doi:10.1016/j.geomorph.2014.03.008.

6. Tarolli, P.; Sofia, G. Human topographic signatures and derived geomorphic processes across landscapes. Geomorphology 2016, 255, 140-161, doi:10.1016/j.geomorph.2015.12.007.

7. Bewley, R.H.; Crutchley, S.P.; Shell, C.A. New light on an ancient landscape: lidar survey in the Stonehenge World Heritage Site. Antiquity 2015, 79, 636-647, doi:10.1017/s0003598x00114577. 
8. Devereux, B.J.; Amable, G.S.; Crow, P.; Cliff, A.D. The potential of airborne lidar for detection of archaeological features under woodland canopies. Antiquity 2015, 79, 648-660, doi:10.1017/s0003598x00114589.

9. Doneus, M.; Briese, C. Full-waveform, airborne laser scanning as a tool for archaeological reconnaissance. In Proceedings of 2nd International Conference on Remote Sensing in Archaeology, Rome, Italy, December 2-4, 2006; pp. 99-105.

10. Doneus, M.; Briese, C. Airborne Laser Scanning in forested areas - potential and limitations of an archaeological prospection technique. In Proceedings of Proceedings of the 11th EAC Heritage Management Symposium, Reykjavik, Iceland, 25-27 March 2010; pp. 53-76.

11. Holden, N.; Horne, P.; Bewley, R.H. High-resolution digital airborne mapping and Archaeology. In Aerial archaeology: developing future practice, Bewley, R., Raczkowski, W., Eds. IOS Press: Amsterdam, Netherland, 2002; pp. 173-180.

12. Opitz, R.S.; Cowley, D. Interpreting Archaeological Topography: Airborne Laser Scanning, 3D Data and Ground Observation. In Interpreting Archaeological Topography. Airborne Laser Scanning, 3D Data and Ground Observation, Opitz, R.S., Cowley, D., Eds. Oxbow Books: Oxford, UK, 2013; pp. 1-13.

13. Shell, C.A.; Roughley, C.F. Exploring the Loughcrew landscape: a new approach with airborne lidar. Archaeology Ireland 2004, 18, 22-25.

14. Sittler, B. Revealing historical landscapes by using airborne laser scanning. A 3-D modell of ridge and furrow in forests near Rastatt (Germany). In Proceedings of Proceedings of the ISPRS Working Group 8/2, Freiburg, Germany, October 3-6, 2004; pp. 258-261.

15. Trier, Ø.D.; Cowley, D.C.; Waldeland, A.U. Using deep neural networks on airborne laser scanning data: Results from a case study of semi-automatic mapping of archaeological topography on Arran, Scotland. Archaeological Prospection 2018, 26, 165-175, doi:10.1002/arp.1731.

16. Sevara, C.; Pregesbauer, M.; Doneus, M.; Verhoeven, G.; Trinks, I. Pixel versus object - A comparison of strategies for the semi-automated mapping of archaeological features using airborne laser scanning data. Journal of Archaeological Science: Reports 2016, 5, 485-498, doi:10.1016/j.jasrep.2015.12.023.

17. Trier, Ø.D.; Zortea, M.; Tonning, C. Automatic detection of mound structures in airborne laser scanning data. Journal of Archaeological Science: Reports 2015, 2, 69-79, doi:10.1016/j.jasrep.2015.01.005.

18. Trier, Ø.D.; Salberg, A.B.; Pilø, L.H. Semi-automatic mapping of charcoal kilns from airborne laser scanning data using deep learning. In Proceedings of Proceedings of the 44th Conference on Computer Applications and Quantitative Methods in Archaeology, Oslo, Norway, 29 March-2 April 2016; pp. 221-231.

19. Trier, Ø.D.; Pilø, L.H.; Johansen, H.M. Semi-automatic mappingof cultural heritage from airborne laser scanning data. Sémata 2015, 27, 159-186.

20. Gallwey, J.; Eyre, M.; Tonkins, T.; Coggan, J. Bringing Lunar LiDAR Back Down to Earth: Mapping Our Industrial Heritage through Deep Transfer Learning. Remote Sensing 2019, 11, doi:10.3390/rs11171994.

21. Verschoof-van der Vaart, W.B.; Lambers, K. Learning to Look at LiDAR: The Use of R-CNN in the Automated Detection of Archaeological Objects in LiDAR Data from the Netherlands. Journal of Computer Applications in Archaeology 2019, 2, 31-40, doi:10.5334/jcaa.32.

22. De Boer, A. Using Pattern Recognition to Search LIDAR Data for Archeological Sites. In Proceedings of CAA2005. Computer Applications and Quantitative Methods in Archaeology. Proceedings of the 33rd Conference, Tomar, Portugal, March 2005; pp. 245-254. 
23. Menze, B.H.; Ur, J.A.; Sherratt, A.G. Detection of Ancient Settlement Mounds. Photogrammetric Engineering E Remote Sensing 2006, 72, 321-327, doi:10.14358/pers.72.3.321.

24. Lambers, K.; Verschoof-van der Vaart, W.; Bourgeois, Q. Integrating Remote Sensing, Machine Learning, and Citizen Science in Dutch Archaeological Prospection. Remote Sensing 2019, 11, doi:10.3390/rs11070794.

25. Banaszek, Ł.; Cowley, D.; Middleton, M. Towards National Archaeological Mapping. Assessing Source Data and Methodology-A Case Study from Scotland. Geosciences 2018, 8, doi:10.3390/geosciences8080272.

26. Shaw, R.; Corns, A. High resolution LiDAR specifically for archaeology: are we fully exploiting this valuable resource? In Proceedings of Proceedings of the 11th EAC Heritage Management Symposium, Reykjavik, Iceland, 25-27 March 2010; pp. 77-86.

27. Bennett, R.; Welham, K.; Hill, R.a.; Ford, A. A Comparison of Visualization Techniques for Models Created from Airborne Laser Scanned Data. Archaeological Prospection 2012, 19, 41-48, doi:10.1002/arp.1414.

28. Challis, K.; Forlin, P.; Kincey, M. A Generic Toolkit for the Visualization of Archaeological Features on Airborne LiDAR Elevation Data. Archaeological Prospection 2011, 18, 279-289, doi:10.1002/arp.421.

29. Devereux, B.J.; Amable, G.S.; Crow, P. Visualisation of LiDAR terrain models for archaeological feature detection. Antiquity 2015, 82, 470-479, doi:10.1017/s0003598x00096952.

30. Doneus, M. Openness as Visualization Technique for Interpretative Mapping of Airborne Lidar Derived Digital Terrain Models. Remote Sensing 2013, 5, 6427-6442, doi:10.3390/rs5126427.

31. Kokalj, Ž.; Zakšek, K.; Oštir, K. Application of sky-view factor for the visualisation of historic landscape features in lidar-derived relief models. Antiquity 2015, 85, 263-273, doi:10.1017/s0003598x00067594.

32. Trier, Ø.D.; Larsen, S.Ø.; Solberg, R. Automatic detection of circular structures in high-resolution satellite images of agricultural land. Archaeological Prospection 2009, 16, 1-15, doi:10.1002/arp.339.

33. Hesse, R. LiDAR-derived Local Relief Models - a new tool for archaeological prospection. Archaeological Prospection 2010, 10.1002/arp.374, n/a-n/a, doi:10.1002/arp.374.

34. Kokalj, Ž.; Zakšek, K.; Oštir, K. Visualizations of Lidar Derived Relief Models. In Interpreting Archaeological Topography: Airborne Laser Scanning, 3D Data and Ground Observation, Opitz, R.S., Cowley, D., Eds. Oxbow Books: Oxford, UK, 2013; Vol. 5, pp. 100-114.

35. Zakšek, K.; Oštir, K.; Kokalj, Ž. Sky-View Factor as a Relief Visualization Technique. Remote Sensing 2011, 3, 398-415, doi:10.3390/rs3020398.

36. Davis, D.S.; Sanger, M.C.; Lipo, C.P. Automated mound detection using lidar and object-based image analysis in Beaufort County, South Carolina. Southeastern Archaeology 2018, 38, 23-37, doi:10.1080/0734578x.2018.1482186.

37. Freeland, T.; Heung, B.; Burley, D.V.; Clark, G.; Knudby, A. Automated feature extraction for prospection and analysis of monumental earthworks from aerial LiDAR in the Kingdom of Tonga. Journal of Archaeological Science 2016, 69, 64-74, doi:10.1016/j.jas.2016.04.011.

38. Riley, M.A. Automated Detection of Prehistoric Conical Burial Mounds from LiDAR Bare-earth Digital Elevation Models. Northwest Missouri State University Maryville, USA, 2009.

39. Schneider, A.; Takla, M.; Nicolay, A.; Raab, A.; Raab, T. A Template-matching Approach Combining Morphometric Variables for Automated Mapping of Charcoal Kiln Sites. Archaeological Prospection 2015, 22, 45-62, doi:10.1002/arp.1497. 
40. Trier, Ø.D.; Zortea, M.; Larsen, S.O. Semi-automatic detection of burial mounds in forested areas. In Proceedings of 32nd EARSeL Symposium Proceedings, Mykonos Island, Greece, 21 May - 24 May 2012.

41. Guyot, A.; Hubert-Moy, L.; Lorho, T. Detecting Neolithic Burial Mounds from LiDAR-Derived Elevation Data Using a Multi-Scale Approach and Machine Learning Techniques. Remote Sensing 2018, 10, doi:10.3390/rs10020225.

42. Hanus, K.; Evans, D. Imaging the Waters of Angkor: A Method for Semi-Automated Pond Extraction from LiDAR Data. Archaeological Prospection 2016, 23, 87-94, doi:10.1002/arp.1530.

43. Meyer, M.; Pfeffer, I.; Jürgens, C. Automated Detection of Field Monuments in Digital Terrain Models of Westphalia Using OBIA. Geosciences 2019, 9, doi:10.3390/geosciences9030109.

44. Trier, Ø.D.; Pilø, L.H. Automatic Detection of Pit Structures in Airborne Laser Scanning Data. Archaeological Prospection 2012, 19, 103-121, doi:10.1002/arp.1421.

45. Caspari, G.; Crespo, P. Convolutional neural networks for archaeological site detection - Finding “princely" tombs. Journal of Archaeological Science 2019, 110, doi:10.1016/j.jas.2019.104998.

46. Caspari, G.; Sadykov, T.; Blochin, J.; Buess, M.; Nieberle, M.; Balz, T. Integrating Remote Sensing and Geophysics for Exploring Early Nomadic Funerary Architecture in the "Siberian Valley of the Kings". Sensors 2019, 19, doi:10.3390/s19143074.

47. Niculiţă, M. A landform classification schema for structural landforms of the Moldavian platform (Romania). In Proceedings of Geomorphometry 2011, Redlands, USA, September 7-11, 2011; pp. 129132.

48. Frachetti, M.D. Pastoralist landscapes and social interaction in bronze age Eurasia; University of California Press: Berkeley, USA, 2008.

49. Nestor, I.; Alexandrescu, A.; Brătianu, A.; Comşa, E.; Perju, S.; Vieru, I. Rapoartele colectivelor arheologice asupra săpturilor din Campania anului 1949 - Studierea societăii omeneşti dela începuturile barbariei, din nordul Moldovei - Activitatea şantierului de săpături arheologice Iaşi-Botoşani-Dorohoi. SCIV 1950, 1, 27-32.

50. Nestor, I.; Alexandrescu, A.; Comşa, E.; Zaharia-Petrescu, E.; Zirra, V. Săpăturile de pe şantierul Valea Jijiei (Iaşi-Botoşani-Dorohoi) în anul 1950. SCIV 1951, 2, 51-76.

51. Frînculeasa, A.; Preda, B.; Heyd, V. Pit-Graves, Yamnaya and Kurgans along the Lower Danube: Disentangling IVth and IIIrd Millennium BC Burial Customs, Equipment and Chronology. Praehistorische Zeitschrift 2015, 90, doi:10.1515/pz-2015-0002.

52. Heyd, V. Yamnaya Groups and Tumuli west of the Black Sea. In Proceedings of Proceedings of the International Conference held in Udine, Udine, Italy, May 15th-18th 2008; pp. 535-555.

53. Cihodaru, C.; Vulpe, R.; Petre, R.; Kiss, Ş. Cercetările arheologice dela Şuletea şi Bârlăleşti - raionul Murgeni. SCIV 1951, 2, 217-288.

54. Diaconu, V. Unele date privind epoca bronzului pe valea Başeului. Forum Cultural 2007, 7, 4-8.

55. Moscalu, E. Săpăturile de salvare de la Cotîrgaci - Comuna Roma, județul Botoşani. Hierasus 1989, 7-8, 117-145.

56. Bichir, G. Sarmaţii la Dunărea de jos în lumina ultimelor cercetări. Pontica 1972, 5, 137-176.

57. Buzdugan, C.; Alexoaie, I. Săpături arheologice într-un tumul din comuna Roma - județul Botoşani. Hierasus 1989, 7-8, 105-115.

58. Petrescu-Dîmbovița, M.; Bîrsan, M.; Bold, E.; Boroneanț, V.; Cazacu, P.; Dinu, M.; Mateescu, C.; Zaharia, E.; Zaharia, N. Șantierul arheologic Hlincea Iași. SCIV 1952, 4, 233-251. 
59. Şovan, O.L. Repertoriul arheologic al Județului Botoşani, 2 ed.; Muzeul Județean Botoşani: Botoșani, Romania, 2016.

60. Odobescu, A. Rămăşițe antice din județul Dorohoi. In Opere Complete, Minerva: București, Romania, 1908; pp. 118-166.

61. Tudor, D.; Vulpe, R.; Vulpe, E.; Berlescu, N.; Bene, A.; Cazacu, P.; Belindeanu, Z. Șantierul Corlățeni. SCIV 1953, 4, 394-431.

62. Barczi, A.; Tóth, T.M.; Csanádi, A.; Sümegi, P.; Czinkota, I. Reconstruction of the paleo-environment and soil evolution of the Csípo"-halom kurgan, Hungary. Quaternary International 2006, 156-157, 49-59, doi:10.1016/j.quaint.2006.05.024.

63. Niculita, M.; Margarint, M.C.; Cristea, A.I. Using archaeological and geomorphological evidence for the establishment of a relative chronology and evolution pattern for Holocene landslides. PLoS One 2019, 14, e0227335, doi:10.1371/journal.pone.0227335.

64. Owen, R. On the Anatomy of Vertebrates: Mammals; Longmans, Green and Company: 1868; Vol. 3.

65. Pike, R.J.; Evans, I.S.; Hengl, T. Chapter 1 Geomorphometry: A Brief Guide. In Geomorphometry Concepts, Software, Applications, 2009; 10.1016/s0166-2481(08)00001-9pp. 3-30.

66. Olaya, V. Chapter 6 Basic Land-Surface Parameters. In Geomorphometry - Concepts, Software, Applications, 2009; 10.1016/s0166-2481(08)00006-8pp. 141-169.

67. MacMillan, R.A.; Shary, P.A. Chapter 9 Landforms and Landform Elements in Geomorphometry. In Geomorphometry - Concepts, Software, Applications, 2009; 10.1016/s0166-2481(08)00009-3pp. 227-254.

68. Evans, I.S.; Hengl, T.; Gorsevski, P. Chapter 22 Applications in Geomorphology. In Geomorphometry Concepts, Software, Applications, 2009; 10.1016/s0166-2481(08)00022-6pp. 497-525.

69. Huggett, R.J. Soil landscape systems: A model of soil Genesis. Geoderma 1975, 13, 1-22, doi:10.1016/00167061(75)90035-x.

70. Niculiţă, M. Realizarea unui cadru de lucru pentru analiza geomorfometrică a reliefului reprezentat pe modele numerice ale suprafeței terenului. PhD Thesis, Alexandru Ioan Cuza University of Iaşi, Iași, Romania, 2012.

71. Greysukh, V.L. The Possibility of Studying Landforms by Means of Digital Computers. Soviet Geography 2014, 8, 137-149, doi:10.1080/00385417.1967.10770905.

72. Johnston, E.G.; Rosenfeld, A. Digital Detection of Pits, Peaks, Ridges, and Ravines. IEEE Transactions on Systems, Man, and Cybernetics 1975, SMC-5, 472-480, doi:10.1109/tsmc.1975.5408443.

73. Peucker, T.K.; Douglas, D.H. Detection of Surface-Specific Points by Local Parallel Processing of Discrete Terrain Elevation Data. Computer Graphics and Image Processing 1975, 4, 375-387, doi:10.1016/0146-664x(75)90005-2.

74. Team, R.C. R: A language and environment for statistical computing, version 3.6.2; R Foundation for Statistical Computing: Vienna, Austria, 2019.

75. Bivand, R.S.; Keitt, T.; Rowlingson, B. rgdal: Bindings for the Geospatial Data Abstraction Library, R package 2019.

76. Bivand, R.S.; Pebesma, E.J.; Gomez-Rubio, V. Applied spatial data analysis with R, 2 ed.; Springer: NY, USA, 2013.

77. Hijmans, R.J. raster: Geographic Data Analysis and Modeling, R package 2019.

78. Pebesma, E.J.; Bivand, R.S. Classes and methods for spatial data in R. R News 2005, 5, 9-13. 
79. Beucher, S.; C., L. Use of watersheds in contour detection. In Proceedings of Proceedings of the International Workshop on image processing: Real-time edge and motion detection/estimation, Rennes, France, 17-21 September 1979; p. 12.

80. Meyer, F.; Beucher, S. Morphological segmentation. Journal of Visual Communication and Image Representation 1990, 1, 21-46, doi:10.1016/1047-3203(90)90014-m.

81. Vincent, L. Morphological grayscale reconstruction in image analysis: applications and efficient algorithms. IEEE Trans Image Process 1993, 2, 176-201, doi:10.1109/83.217222.

82. Vincent, L.; Soille, P. Watersheds in digital spaces: an efficient algorithm based on immersion simulations. IEEE Transactions on Pattern Analysis and Machine Intelligence 1991, 13, 583-598, doi:10.1109/34.87344.

83. Conrad, O.; Bechtel, B.; Bock, M.; Dietrich, H.; Fischer, E.; Gerlitz, L.; Wehberg, J.; Wichmann, V.; Böhner, J. System for Automated Geoscientific Analyses (SAGA) v. 2.1.4. Geoscientific Model Development 2015, 8, 1991-2007, doi:10.5194/gmd-8-1991-2015.

84. Iwahashi, J.; Pike, R.J. Automated classifications of topography from DEMs by an unsupervised nestedmeans algorithm and a three-part geometric signature. Geomorphology 2007, 86, 409-440, doi:10.1016/j.geomorph.2006.09.012.

85. Iwahashi, J.; Kamiya, I. Landform Classification Using Digital Elevation Model by the Skills of Image Processing. Geoinformatics 1995, 6, 97-108, doi:10.6010/geoinformatics1990.6.2_97.

86. Wood, J. The geomorphological characterisation of digital elevation models. PhD Thesis, University of Leicester, Leicester, UK, 1996.

87. Evans, I.S. An integrated system of terrain analysis and slope mapping; University of Durham: Durham, UK, 1979.

88. Yokoyama, R.; Shirasawa, M.; Pike, R.J. Visualizing topography by openness: a new application of image processing to digital elevation models. Photogrammetric engineering $\mathcal{E}$ Remote Sensing 2002, 68, 257-265.

89. Kiss, R. Determination of drainage network in digital elevation models, utilities and limitations. Journal of Hungarian Geomathematics 2004, 2, 16-29.

90. Koethe, R.; Lehmeier, F. SARA - System zur Automatischen Relief-Analyse. User Manual, 2 ed.; Department of Geography, University of Goettingen: 1996.

91. Riley, S.J.; DeGloria, S.D.; Elliot, R. A terrain ruggedness index that quantifies topographic heterogenity. Intermountain Journal of Sciences 1999, 5, 23-27.

92. Gerlitz, L.; Conrad, O.; Böhner, J. Large-scale atmospheric forcing and topographic modification of precipitation rates over High Asia \&ndash; a neural-network-based approach. Earth System Dynamics 2015, 6, 61-81, doi:10.5194/esd-6-61-2015.

93. Böhner, J.; Antonić, O. Chapter 8 Land-Surface Parameters Specific to Topo-Climatology. In Geomorphometry - Concepts, Software, Applications, 2009; 10.1016/s0166-2481(08)00008-1pp. 195-226.

94. Wilson, J.; Gallant, J. Primary Topographic Attributes. In Terrain Analysis: Principles and Applications, Wilson, J.P., Gallant, J.C., Eds. John Wiley \& Sons: 2000; pp. 51-85.

95. Guisan, A.; Weiss, S.B.; Weiss, A.D. Plant Ecology 1999, 143, 107-122, doi:10.1023/a:1009841519580.

96. Weiss, A.D. Topographic Position and Landforms Analysis. In Proceedings of 20th Annual ESRI User Conference, San Diego, CA, USA.

97. Freeman, T.G. Calculating catchment area with divergent flow based on a regular grid. Computers $\mathcal{E}$ Geosciences 1991, 17, 413-422, doi:10.1016/0098-3004(91)90048-i. 
98. Böhner, J.; Selige, T. Spatial prediction of soil attributes using terrain analysis and climate regionalisation. In SAGA - Analysis and Modelling Applications, Boehner, J., McCloy, K.R., Strobl, J., Eds. Georg-August-Universität Göttingen: Goettingen, 2006; Vol. 115, pp. 13-28.

99. Olaya, V. Hidrologia computacional y modelos digitales del terreno. Teorna, practica y filosofia de una nueva forma de analisis hidrologico.; 2004.

100. Boehner, J.; Koethe, R.; Conrad, O.; Gross, J.; Ringeler, A.; Selige, T. Soil Regionalisation by Means of Terrain Analysis and Process Parameterisation. In Soil Classification 2001, Micheli, E., Nachtergaele, F., Montanarella, L., Eds. European Soil Bureau: Luxembourg, 2002; Vol. Research Report No. 7, EUR 20398 EN pp. 213-222.

101. Lang, S.; Blaschke, T. Landschaftsanalyse mit GIS; Verlag Eugen Ulmer Stuttgart, 2007.

102. Forman, R.; Godron, M.; Wiley: 1986.

103. Breiman, L. Machine Learning 2001, 45, 5-32, doi:10.1023/a:1010933404324.

104. Liaw, A.; Wiener, W. Classification and Regression by randomForest. $R$ News 2002, 2, 18-22.

105. Breiman, L. Classification and Regression Trees; Routledge: 2017.

106. Liaw, A.; Wiener, M. Classification and Regression by randomForest. $R$ News 2002, 2, 18-22.

107. Ishwaran H.; U., K. Random survival forests for R. R News 2007, 7, 25-31.

108. Ishwaran, H.; Kogalur, U.B.; Blackstone, E.H.; Lauer, M.S. Random survival forests. The Annals of Applied Statistics 2008, 2, 841-860, doi:10.1214/08-aoas169.

109. Ishwaran H; U, K. Fast Unified Random Forests for Survival, Regression, and Classification (RF-SRC), version 2.9.2; R package 2019.

110. Paluszynska, A.; Biecek, P.; Jiang, Y. randomForestExplainer: Explaining and Visualizing Random Forests in Terms of Variable Importance, version 0.10.0; R package: 2019.

111. Greenwell, B.M. pdp: An R Package for Constructing Partial Dependence Plots. The R Journal 2017, 9, doi:10.32614/rj-2017-016.

112. Kursa, M.B.; Rudnicki, W.R. Feature Selection with theBorutaPackage. Journal of Statistical Software 2010, 36, doi:10.18637/jss.v036.i11.

113. O'Brien, R.; Ishwaran, H. A Random Forests Quantile Classifier for Class Imbalanced Data. Pattern Recognit 2019, 90, 232-249, doi:10.1016/j.patcog.2019.01.036.

114. Roudier, P.; Brugnard, C.; Beaudette, D.; Louis , B. clhs: Conditioned Latin Hypercube Sampling, version 0.7-2; R package: 2019.

115. Roudier, P.; Beaudette, D.E.; Hewitt, A.E. A conditioned Latin hypercube sampling algorithm incorporating operational constraints. In Proceedings of Digital Soil Assessments and Beyond: Proceedings of the 5th Global Workshop on Digital Soil Mapping, Sydney, Australia; pp. 1-6.

116. Minasny, B.; McBratney, A.B. A conditioned Latin hypercube method for sampling in the presence of ancillary information. Computers $\mathcal{E}$ Geosciences 2006, 32, 1378-1388, doi:10.1016/j.cageo.2005.12.009.

117. Brenning, A.; Bangs, D.; Becker, M. RSAGA: SAGA Geoprocessing and Terrain Analysis, R package 2018.

118. Deng, Y.; Wilson, J.P. Multi-scale and multi-criteria mapping of mountain peaks as fuzzy entities. International Journal of Geographical Information Science 2008, 22, 205-218, doi:10.1080/13658810701405623. 